\title{
Historical roasting of thallium- and arsenic-bearing pyrite: Current Tl pollution in the Riotinto mine area
}

\author{
Paula López-Arce ${ }^{\mathrm{a}, 1}$, Fernando Garrido ${ }^{\mathrm{a}, *}$, Javier García-Guinea ${ }^{\mathrm{a}}$, Andreas Voegelin ${ }^{\mathrm{b}}$, \\ Jörg Göttlicher ${ }^{\mathrm{c}}$, Jose Miguel Nieto ${ }^{\mathrm{d}}$ \\ ${ }^{a}$ Museo Nacional de Ciencias Naturales (CSIC), C/ José Gutiérrez Abascal, 2, 28026, \\ Madrid (Spain)
}

${ }^{b}$ Eawag, Swiss Federal Institute of Aquatic Science and Technology, Department of Water Resources and Drinking Water, Überlandstrasse 133, CH-8600 Dübendorf (Switzerland)
${ }^{c}$ Karlsruhe Institute of Technology, Institute for Photon Science and Synchrotron Radiation, KIT Campus North, Hermann-von-Helmholtz-Platz 1, D-76344 Eggenstein- Leopoldshafen (Germany)

${ }^{\mathrm{d}}$ Department of Earth Sciences, University of Huelva, 21071 Huelva (Spain)

'‘Present address': The Bartlett School of Environment, Energy and Resources, University College London, 22 Gordon Street, London, WC1H 0QB, UK - Property Care Association, 11 Ramsay Court Kingfisher Way, Huntingdon, PE29 6FY, UK.

*Corresponding author.

Phone: +34914111328; E-mail: fernando.garrido@mncn.csic.es

This document is the accepted manuscript version of the following article:

López-Arce, P., Garrido, F., García-Guinea, J., Voegelin, A., Göttlicher, J., \& Nieto, J. M. (2019). Historical roasting of thallium- and arsenic-bearing pyrite: current $T 1$ pollution in the Riotinto mine area. Science of the Total Environment, 648, 1263-1274. https://doi.org/10.1016/j.scitotenv.2018.08.260 


\section{Abstract}

Samples of an open-air pyrite roasting heap from the $19^{\text {th }}$ century in the Riotinto mine area (SW Spain) and surrounding sediments and soil along a seasonal surface runoff channel were analyzed to study thallium ( $\mathrm{Tl}$ ) phase transformations during historical roasting of Tl-bearing arsenian pyrite, secondary weathering processes, $\mathrm{Tl}$ dispersion and current environmental pollution. Results from Electron Probe Microanalyses (EPMA) indicate an even distribution of $\mathrm{Tl}$ in pyrite grains of an ore sample $\left(22 \mathrm{mg} \mathrm{kg}^{-1}\right.$ total $\mathrm{Tl}$ ), suggesting that $\mathrm{Tl}$ is incorporated in the pyrite structure rather than in discrete Tl-sulfide microparticles. The roasting residue $\left(122 \mathrm{mg} \mathrm{kg}^{-1}\right.$ total $\left.\mathrm{Tl}\right)$ consists mainly of hematite. EPMA suggested that $\mathrm{Tl}$ in the roasting residue and contaminated soil was cooccuring with $\mathrm{Fe}$ oxide particles, with a mean $\mathrm{Tl}$ point concentration of $0.12 \%$ in samples from the roasting residues. Total concentrations of $\mathrm{Tl}$ in soil samples decrease with distance from the roasting heap to $14 \mathrm{mg} \mathrm{kg}^{-1}$. X-ray absorption near-edge structure (XANES) spectra collected on pyrite roasting residue and a soil sample suggest that most $\mathrm{Tl}$ is $\mathrm{Tl}(\mathrm{I})$ substituting $\mathrm{K}$ in jarosite. Sequential extractions show that most $\mathrm{Tl}(85-99 \%)$ in the soil and sediment samples is concentrated in the residual fraction and, thus, is rather strongly bound. Lastly, water extracts indicate that colloidal particles (i.e. $<1 \mu \mathrm{m}$ size) may contribute to the dispersion of $\mathrm{Tl}$ around and away from the roasting heaps.

Keywords: Thallium; Tl-jarosite; Riotinto mine; environmental pollution; Tl XANES; colloids. 


\section{Introduction}

Thallium ( $\mathrm{Tl})$ is a metal that can exhibit high potential cytotoxicity and genotoxicity in its two main oxidation states (I and III) to humans (Rodríguez-Mercado et al., 2017). Worldwide, the $\mathrm{Tl}$ content of soils depends on the geological origin of the parent material (Sager, 1998). Although Tl concentrations in surface soils range from 0.1 to 2 $\mathrm{mg} \mathrm{kg}^{-1}$, with most reported concentrations being $<1 \mathrm{mg} \mathrm{kg}^{-1}$ (Fergusson, 1990; Tremel et al., 1997), it occurs at higher concentrations in environments associated with epithermal metallogeneses $\left(<200{ }^{\circ} \mathrm{C}\right)$ of sulfide minerals (Sobott, 1995). Natural mineralization or mining of Tl-rich sulfide minerals can produce $\mathrm{Tl}$ pollution in the environment, raising environmental concerns in China and other parts of the world (Xiao et al., 2012; Baceva et al., 2014). Anthropogenic Tl contamination mainly results from mining of Tl-rich sulfide minerals (Vanek et al., 2013; Romero et al., 2015), acid mine drainage (Casiot et al., 2011) and tailings spills such as the dam failure accident of Aznalcóllar mine (Spain) in 1998 (Martin et al., 2004). Also, atmospheric emissions and deposition from industrial processes that involve Tl-bearing pyrites have resulted in increased $\mathrm{Tl}$ concentrations in the vicinity of metal smelters and coal-burning power plants (Zhuang et al., 2012; Karbowska, 2016), sulfuric acid production plants (Oliveira et al., 2012), or cement production plants (Kersten et al., 2014).

Due to mining activities, $\mathrm{Tl}$ concentrations above $100 \mathrm{mg} \mathrm{kg}^{-1}$ have been reported in soils affected by mining industries in China (Xiao et al., 2012), Poland (Lis et al., 2003) or France (Tremel et al., 1997). Pyrite-containing ores may contain a wide range of toxic elements in variable concentrations, such as $\mathrm{Cd}, \mathrm{Pb}$ or $\mathrm{Tl}$ (Lopez-Anton et al., 2015, Gomez-Gonzalez et al., 2015) that may disperse into the environment from roasting wastes (Srinivasachar et al., 1990; Lin and Qvarfort, 1996; Hu et al., 2006). Once in the soil-water system, $\mathrm{Tl}$ becomes a harmful element mainly because its similarity between $\mathrm{Tl}^{+}$and $\mathrm{K}^{+}$ions (Xiao et al., 2004). For instance, Tl levels in human urine and hair were associated with residency in zones containing water with elevated $\mathrm{Tl}$ concentrations in Tuscany region (Italy) (Campanella et al., 2016). The rural area of Lanmuchang (China) was identified to have high $\mathrm{Tl}$ contents in local ecosystems due to the weathering of Tl-bearing sulfide minerals, and was found to be affected by endemic $\mathrm{Tl}$ poisoning (Zhou and Liu, 1985). A comprehensive critical review on $\mathrm{Tl}$ uses, sources, and occurrence in the environment can be found in Belzile and Chen (2017). Further studies are needed to identify other potential sources of $\mathrm{Tl}$ and develop effective 
monitoring protocols of its concentration to limit the negative impact on the environment and human health (Karbowska, 2016; Caritat and Reimann, 2017).

The Riotinto mining area (SW Spain) is considered the largest volcanogenic massive sulfide district worldwide (Fig.1), with more than 400 million tons of massive sulfide deposits and 2,000 million tons of stockwork (García Palomero, 1992; Tornos and Heinrich, 2008). It has been mined since the Chalcolithic period, 4500 years ago, and intensively exploited during the $19^{\text {th }}$ and $20^{\text {th }}$ centuries (Romero et al., 2015). The Tinto River drains the eastern part of the Iberian Pyrite Belt (IPB), displaying high metal(oid) concentrations in solution and low $\mathrm{pH}$ values. These extreme conditions are caused by intense mining, especially during the period 1850-2001, while natural formation of acid rock drainage has been considered negligible (Olías and Nieto, 2015). By the beginning of the $19^{\text {th }}$ century, the process of slow roasting (over six months) of portions of 40-50 tons of low grade $\mathrm{Cu}$-containing pyritic ores placed in conical heaps ("teleras") was applied to remove $\mathrm{S}$ for subsequent $\mathrm{Cu}$ extraction. The calcination "teleras" aggravated the environmental and public health problems associated with the mining activities due to the large volumes of toxic clouds of As-S-containing fumes emitted to the atmosphere (Ferrero Blanco, 1999), so the area became known as "The Valley of Lucifer" (Carrasco Martiañez, 2000). Although, Tl is a highly volatile element (Yan et al., 2001), relatively stable Tl-bearing mineral phases commonly associated to pyrite ores may limit Tl volatilization during roasting (Yang et al., 2009). As a result, Tl can remain incorporated into the final crystalline Fe oxides or partially retained in the solid phase roasting wastes (Yang et al., 2009; Chen et al., 2013). The accumulative or volatile behavior of $\mathrm{Tl}$ during roasting of Tl-bearing pyrite ores depends on the initial chemistry and mineralogy, concentration and accessory minerals, and final burning temperature (Lopez-Arce et al., 2017). The calcinations were gradually cancelled but the associated water pollution of rivers continued with the increase in mining production until the end of the $20^{\text {th }}$ century (Olías and Nieto, 2015) when the mining activity was discontinued. However, several calcination teleras remain on site. These characteristic residues, enriched in $\mathrm{Tl}$ and other metal(oid)s after the roasting process, have become a source of contaminants as they are exposed to weathering. Thallium dissemination to adjacent soils depends on the transport pattern which is mainly associated to natural streams, and on the mechanisms by which $\mathrm{Tl}$ is transferred to other environments. In addition to the transport of dissolved $\mathrm{Tl}$, the potential role of colloids in $\mathrm{Tl}$ transport should also be assessed. 
Within the historic Riotinto mine district, the release of $\mathrm{Tl}$ from pyrite ores, the effect of roasting on $\mathrm{Tl}$ release and speciation in roasting residues, and the dispersion of $\mathrm{Tl}$ into the soil environment can be studied within a well-constrained area.The goal of this research is to provide insights of the chemical behavior and distribution of geogenic $\mathrm{Tl}$ in polluted soils through a detailed physico-chemical and mineralogical characterization of samples collected from Riotinto polymetallic mine district.

\section{Materials and Methods}

\subsection{Geological context and sampling}

The studied area corresponds to the North and South zones of Riotinto mining district (Huelva, SW Spain), close to Nerva town and Zarandas areas, respectively (Fig.1a). An initial sample collection over the two areas in search for significant $\mathrm{Tl}$ contents consisted in seven-teen samples of mining wastes, stream sediments and soils (Table $\mathrm{S} 1)$, together with pyrite ores and gossan rocks whose mineralogical and chemical compositions are provided as supplementary information (Tables S2 and S3). A second sampling stage was focused on a historic "telera" roasting system (Fig. 1b). This gathers samples from brittle pyrite ores (Fig. 1c) originally used in the roasting process (RT16), an open-air pyrite roasting heap from the $19^{\text {th }}$ century (RT2) and sediments and soil samples (RT3, RT4, and RT5) taken at 60, 90 and $250 \mathrm{~m}$ from the "telera" (RT2) along a small creek collecting surface acid water from this (Fig. 1b).

From all those locations (Fig. 1d), approximately two $\mathrm{kg}$ of sample were collected. In the laboratory, all samples were dried at $40^{\circ} \mathrm{C}$ during 72 hours, then weakly rolled to break soil clods, homogenized, sieved ( $2 \mathrm{~mm}$ mesh) and transferred to polypropylene containers prior to analysis.

\subsection{Chemical and mineralogical analysis}

Total digestion of duplicated $0.25 \mathrm{~g}$ finely milled samples was performed using the sequential addition of hydrofluoric $(\mathrm{HF})$, hydrochloric $(\mathrm{HCl})$, nitric $\left(\mathrm{HNO}_{3}\right)$ and perchloric acids $\left(\mathrm{HClO}_{4}\right)$ at $230^{\circ} \mathrm{C}$. Multi-element total composition of solution samples were determined by Inductively Coupled Plasma-Optical Emission Spectroscopy (ICPOES; Agilent 725-ES) for major elements and Inductively Coupled Plasma-Mass Spectrometry (ICP-MS; Perkin Elmer NexION 300D) for trace and rest of elements. All ICP analyses were made by MS-Analytical laboratory, Langley (Canada). Any 
volatilization losses occurring during digestion could result in the partial recovery of elements such as As. All the chemicals used for sample preservation and analysis were of reagent grade quality or higher. Ultrapure water $\left(18 \mathrm{M} \Omega \mathrm{cm}^{-1}\right.$, Milli Q+, Millipore Corp.) was used for all solutions and dilutions. Samples were analyzed with suitable reference materials, blanks, and duplicates. Corrections were also made for spectral inter-element interferences. A certified reference material (CRM, National Institute of Standards and Technology, USA) was used to perform a quality assessment and to check the validity of the digestion method. This CRM or Standard Reference Material ${ }^{\circledR}$ 2710a (Montana I Soil) provides a reference value for total $\mathrm{Tl}$ content of $1.52 \pm 0.02 \mathrm{mg}$ $\mathrm{kg}^{-1}$ on a dry-mass basis.

Additional duplicate $0.15 \mathrm{~g}$ samples were mixed with sodium peroxide $\left(\mathrm{Na}_{2} \mathrm{O}_{2}\right)$ and sodium hydroxide $(\mathrm{NaOH})$ and fused in preheated muffle furnace for Si quantification. Fused samples were then dissolved in dilute $\mathrm{HCl}$ and final solutions were analyzed by ICP-AES (Thermo iCAP6000). Results are reported as $\mathrm{SiO}_{2}$ at levels $0.1 \%$ to $50 \%$. Lastly, analysis of $\mathrm{S}, \mathrm{C}, \mathrm{H}$, and $\mathrm{N}$ contents were performed on an elemental microanalyzer LECO model CHNS-932. Milled $1 \mathrm{mg}$ duplicate samples were heated at $990^{\circ} \mathrm{C}$ with $\mathrm{He}$ as a carrier gas. To determine $\mathrm{C}\left(\mathrm{CO}_{2}\right), \mathrm{H}\left(\mathrm{H}_{2} \mathrm{O}\right)$ and $\mathrm{S}\left(\mathrm{SO}_{2}\right)$ from the thermal decomposition of the samples, infrared detectors were applied; a thermal conductivity detector was used to quantify $\mathrm{N}\left(\mathrm{N}_{2}\right)$.

The semi-quantitative mineralogical composition of the total powder $(\leq 2 \mathrm{~mm})$ and clay $(\leq 2 \mu \mathrm{m})$ fractions of the samples was determined by X-ray diffraction (XRD). Samples were milled with a mechanical agate mortar over $15 \mathrm{~min}$ and pressed to produce pellets of powdered aliquots. Samples showing a total powder XRD-peak at d-spacing of 4.45, were selected for the mineralogical characterization of their clay fraction. To obtain the clay fraction, a sedimentation-based extraction protocol consisting of four extractions with ammonia addition, at $20 \pm 2^{\circ} \mathrm{C}$ and $8 \mathrm{~h}$ of sedimentation time. Further oriented aggregation, addition of ethylene-glycol and heating up to $550^{\circ} \mathrm{C}$ were performed. Diffractograms were obtained with a Panalytical X'Pert diffractometer, using a $\mathrm{CuK} \alpha$ radiation source, step scanning from $3^{\circ}$ to $70^{\circ} 2 \theta$, step size of $0.02^{\circ}$, scan speed of $0.02 \%$ with a count of $1 \mathrm{~s} / \mathrm{step}$ and a setting of $40 \mathrm{kV}$ and $45 \mathrm{~mA}$ for the X-ray tube. The XRD patterns were processed to identify mineral phases and to carry out semiquantitative analysis by pattern maching, using the XPOWDERX and Bruker AXS DiffracPlus EVA software packages with the ICDD-PDF2 and DIFDATA databases. 
Surface area $\left(\mathrm{m}^{2} \mathrm{~g}^{-1}\right)$, pore volume $\left(\mathrm{cm}^{3} \mathrm{~g}^{-1}\right)$ and half pore width $(\AA)$ of $0.3 \pm 0.1 \mathrm{~g}$ of samples were analyzed by means of $\mathrm{N}_{2}$ isotherms and BET method with an Automated Gas Sorption Analyzer, Quantachrome, AUTOSORB 1-MP-11. The software AS1Win ${ }^{\mathrm{TM}}$ V.2.02 of Quantachrome instruments was used to process the obtained data.

Lastly, the $\mathrm{pH}$ and electrical conductivity of samples were measured in deionized water $(1: 5 \mathrm{~m} / \mathrm{m}$ suspension; $5 \mathrm{~g}$ of sample $(<2 \mathrm{~mm})$ in $25 \mathrm{ml}$ of Mili-Q ultrapure water). A portable pH meter Thermo Scientific ORION STAR A221 was used, with an electrode $\mathrm{pH} / \mathrm{ATC}$ ROSS triode (8107UWMMD) with precision \pm 0.002 . Electrical conductivity was measured by a conductivity-meter Thermo Scientific Orion model 125A+.

\subsection{Microscopy observations and point chemical analyses}

The samples (fraction $<2 \mathrm{~mm}$ ) were studied under Environmental Scanning Electron Microscope (ESEM, FEI Inspect Company) in order to observe their morphology, dissolution, corrosion, and re-crystallization features. The semi-quantitative elemental composition was analyzed by means of a coupled X-ray energy-dispersive spectrometer (EDS, Oxford Instruments analytical-INCA). The samples were analyzed both under secondary electrons and backscattered modes, high and low vacuum modes, with and without gold sputtering. In addition, the point chemical composition of mineral particles was studied by means of an Electron Probe Microanalyzer (EPMA). The samples were previously prepared by embedding their $<2 \mathrm{~mm}$ fraction in epoxy resin and further polishing of the obtained cylindrical blocks with sandpaper 1200 and 4000 ASTM mesh and final finishing with alumina $0.3 \mu \mathrm{m}$. A JEOL Superprobe JXA 8900-M coupled with wavelength dispersive spectroscopy (WDS), operating at an accelerating voltage of $20 \mathrm{kV}$, beam current of $40 \mathrm{~mA}$, and 20s counting time, bulk and channel-selected (TAP, PETJ, LIF, PETH) X-ray spectra search and identification routines were used. Electron beam was $\sim 5 \mu \mathrm{m}$ in diameter. Thallium sulfides, weissbergite $\left(\mathrm{TlSbS}_{2}\right)$ and parapierrotite $\mathrm{Tl}(\mathrm{Sb}, \mathrm{As})_{5} \mathrm{~S}_{8}$, from the mineral assemblage of Lookout Pass Area, Utah (USA), were used for $\mathrm{Tl}(\mathrm{M} \alpha)$ calibration. Standard specimens and X-ray lines used for calibration and measurements of additional element analyses were $\mathrm{Zn}_{3} \mathrm{As}_{2}$ (As-L $\alpha$ ), $\operatorname{HgTe}(\mathrm{Hg}-\mathrm{M} \alpha), \mathrm{Fe}_{2} \mathrm{O}_{3}(\mathrm{Fe}-\mathrm{K} \alpha)$, K-Feldspar $(\mathrm{Na}-\mathrm{K} \alpha), \mathrm{CaSiO}_{3}(\mathrm{Si}-\mathrm{K} \alpha), \mathrm{BaS}(\mathrm{Ba}-\mathrm{K} \alpha)$, Pyrite (S-K $\alpha), \mathrm{MnO}(\mathrm{Mn}-\mathrm{K} \alpha), \mathrm{Sb}_{2} \mathrm{O}_{3}(\mathrm{Sb}-\mathrm{L} \alpha), \mathrm{K}-$ Feldspar $(\mathrm{Al}-\mathrm{K} \alpha), \mathrm{PbS}(\mathrm{Pb}-\mathrm{M} \alpha), \mathrm{Cu}^{0}$ $(\mathrm{Cu}-\mathrm{K} \alpha), \mathrm{ClNa}(\mathrm{Cl}-\mathrm{K} \alpha), \mathrm{ZnS}(\mathrm{Zn}-\mathrm{K} \alpha)$. 
Based on the ICP-MS, XRD analyses and SEM observations, four main mineral species were assessed for $\mathrm{Tl}$ and companion elements ( $\mathrm{S}, \mathrm{Mn}, \mathrm{Na}, \mathrm{As}, \mathrm{Hg}, \mathrm{Pb}, \mathrm{Fe}, \mathrm{Al}, \mathrm{Si}, \mathrm{Ba}, \mathrm{K}$, $\mathrm{Cu}, \mathrm{Sb}$, and $\mathrm{Zn}$ ): (1) sulfides (sphalerite, chalcopyrite, pyrite), (2) iron oxides, (3) sulfates (jarosite, plumbojarosite, barite, iron-rich sulfates), and (4) mixtures of mineral phases (Fe oxides/feldspar, Fe oxide/silica, Fe oxide/silica/sulfate). Within each sample, up to 20 grains were analyzed per mineral species by EPMA. Transects of 5 to 10 point measurements were done in each mineral grain.

\subsection{Bulk and micro X-ray absorption spectroscopy.}

The powdered samples RT2 and RT4 (prepared as pellets) were studied by X-ray absorption near-edge structure (XANES) spectroscopy at the $\mathrm{Tl} \mathrm{L}_{\mathrm{III}}$-edge to determine the speciation in the bulk materials. Resin-embedded and polished blocks of the corresponding size fractions $<2 \mathrm{~mm}$ were examined by micro-focused $(\mu-)$ XANES spectroscopy to assess spatial variations in $\mathrm{Tl}$ speciation. The measurements were performed at the SUL-X beamline at the Test Facility and Synchrotron Radiation Source at KIT (Germany). A Si(111) double crystal monochromator was used for X-ray beam energy selection, and a Kirk-Baez mirror system for beam focusing. The incident and transmitted photon flux were measured with ionization chambers, and the fluorescence signal with a 7-element $\mathrm{Si}(\mathrm{Li})$ solid state detector. For photon energy calibration, the spectrum of $\mathrm{Tl}_{2} \mathrm{O}_{3}$ was recorded in transmission mode. A beam size of $200 \times 200 \mu \mathrm{m}^{2}$ was used for bulk analyses on homogenized samples and a beam size of $50 \times 50 \mu \mathrm{m}^{2}$ for point analyses on polished sample blocks. Points of interest (POI) for $\mu$ XANES were selected based on EPMA results obtained on the same polished blocks and were localized by light microscopy.

\subsection{Sequential extraction procedure (SEP)}

To study the chemical partitioning of $\mathrm{Tl}$ and other trace elements, samples of soil, roasting wastes and raw pyrite ores related to the historic "Telera" roasting system were subjected to sequential chemical extraction. This procedure (SEP) was based on the standard method proposed by the Standards Measurement and Testing Programme modified by Yang et al. (2005) (Table 1) and includes four fractions (with hypothetical interpretation in parentheses): FI: $0.11 \mathrm{M}$ acetic acid (exchangeable and weak acidsoluble fraction); FII: $0.1 \mathrm{M}$ hydroxylamine hydrochloride at $\mathrm{pH} 2$ (poorly crystalline or reducible $\mathrm{Al}, \mathrm{Fe}$ and $\mathrm{Mn}$ oxide-hydroxides); FIII: 30\% hydrogen peroxide and $1 \mathrm{M}$ 
ammonium acetate (organic matter or oxidizable phases like sulfides); RF: residual fraction analyzed for total element concentrations by ICP. Ultra-pure deionized water was used for all solutions and dilutions. All glassware used for the experiments were previously soaked in $14 \% \mathrm{HNO}_{3}(\mathrm{v} / \mathrm{v})$ and rinsed with deionized water prior to use. All chemicals used for sample preservation, analysis and reagent preparation were of reagent grade quality or higher. The obtained solutions and final mineral residues were analyzed by ICP-OES and ICP-MS as described above. The CRM 2710a (Montana I Soil) from NIST (USA) was also subjected to the SEP in order to perform a quality assessment and to check the validity of the method.

\subsection{Extraction of dispersible colloidal and dissolved fractions}

The maximum amount ( $\mathrm{mg} \mathrm{kg}^{-1}$ soil) of potentially releasable colloids from the samples was termed dispersible colloidal fraction (DCF) (Serrano et al., 2015; Gomez-Gonzalez et al., 2016). The DCF of selected samples were obtained by leaching $4 \mathrm{~g}$ of the $<2 \mathrm{~mm}$ fractions with ultrapure water (soil/water ratio 1:10) during $24 \mathrm{~h}$ in an end-over-end shaker. Suspensions were subsequently centrifuged at $900 \mathrm{rpm}$ during 10 minutes, and according to Bolea et al. (2010), the resulting supernatants ( 20 mL) corresponded to their DCF. These DCF were pipetted into polypropylene vessels and stored at $4^{\circ} \mathrm{C}$. The following fractions were isolated from the leaching suspensions: (i) the dispersible colloidal fraction $(\mathrm{DCF}, \leq 1000 \mathrm{~nm})$, (ii) the colloidal fraction $(\mathrm{CF}, 1000-10 \mathrm{~nm})$ isolated from the DCF by ultrafiltration using $10 \mathrm{~nm}$ membranes (Pall Microsep ${ }^{\mathrm{TM}}$, Advance, Membrane: Omega, MWCO: $100 \mathrm{kD}$ ), and (iii) the truly water soluble or dissolved fraction (DF, $<10 \mathrm{~nm}$ ) that passed $10-\mathrm{nm}$ pore size ultrafiltration membranes. Therefore, the dispersible colloidal fraction (DCF, $\leq 1000 \mathrm{~nm}$ ) includes both the solid colloids (1000-10 nm) and the dissolved fraction $(\leq 10 \mathrm{~nm})$.

The colloidal mass was isolated and quantified following the procedure described by Plathe et al. (2010) but modified according to Gomez-Gonzalez et al. (2016). Additional fractions of the DCF suspensions were analyzed: (i) DCF aliquots were subjected to ICP-MS analysis for total element concentration; (ii) other DCF aliquots were observed within $48 \mathrm{~h}$ after its preparation under Transmission Electron Microscopy (TEM) coupled to an EDS device (TEM-EDS) in a JEOL 1400+ microscope operating at 100 $\mathrm{kv}$. Besides, aliquots of the dissolved fraction (DF, <10 nm) were analyzed by Ion chromatography (IC, Metrohm Advanced Compac ion chromatographic 867 instrument) to quantify soluble salts: cations $\left(\mathrm{Na}^{+}, \mathrm{K}^{+}, \mathrm{Mg}^{2+}, \mathrm{Ca}^{2+,} \mathrm{NH}_{4}{ }^{+}, \mathrm{Li}^{+}\right)$and anions $\left(\mathrm{Cl}^{-}, \mathrm{Br}^{-}\right.$, 
$\left.\mathrm{SO}_{4}{ }^{=}, \mathrm{NO}_{3}{ }^{-}, \mathrm{NO}_{2}{ }^{-}, \mathrm{PO}_{4}{ }^{\circ}\right)$. Further dilution, $1 / 10$ for $\mathrm{Mg}^{2+}$ and $\mathrm{Ca}^{2+}$ and $1 / 80$ for $\mathrm{SO}_{4}{ }^{=}$, was performed in those samples above upper detection limits. Other DF aliquots were used to determine the element composition by ICP-MS.

\section{Results and discussion}

\subsection{Mineralogy and bulk element composition}

The mineralogical composition of the samples is given in Tables 2, 3, and S1. The concentrations of major and minor elements are in Tables 4 and S2. The pyrite ore sample RT16 consists of $70 \%$ iron sulfide (pyrite), $26 \%$ chalcopyrite and traces of quartz. Its high content in As (above $1100 \mathrm{mg} \mathrm{kg}^{-1}$ ) might be associated with pyrite as arsenical pyrite. Arsenic-rich (arsenian or arsenical) pyrite can contain up to tens of thousands of parts per million (ppm) of toxic metals such as $\mathrm{Hg}, \mathrm{Tl}$, and $\mathrm{Cd}$ and the solid solubility of the aforementioned metals is strongly dependent on the As concentration of pyrite (Deditius and Reich, 2016). Table 4 indicates that sample RT16 also contains $23 \mathrm{mg} \mathrm{kg}^{-1} \mathrm{Tl}$, showing that this is a Tl-bearing arsenical pyrite. Hematite (75\%) and jarosite (20\%) were especially abundant in the sample collected from the open-air pyrite roasting residue (RT2), which contained the highest amount of total Tl $\left(122 \mathrm{mg} \mathrm{kg}^{-1}\right)$. Experimental roasting of Tl-bearing pyrites showed the development of hematite and concentration of $\mathrm{Tl}$ (from 10 to $72 \mathrm{mg} \mathrm{kg}^{-1}$ ) after roasting at $900^{\circ} \mathrm{C}$ in an oxidizing atmosphere (Lopez-Arce et al., 2017). The abundance of hematite can thus be explained by the heating of pyrite in air, which promotes the formation of hematite (Bhargava et al., 2009). Jarosite commonly forms under oxic and acidic conditions where $\mathrm{Fe}(\mathrm{III})$ and $\mathrm{SO}_{4}$ derived from pyrite oxidation combine with $\mathrm{K}$ from silicate dissolution (Lindsay et al., 2015). Interestingly, Tl(I)-substituted jarosite has previously been identified in hematite-rich ash formed by fluid bed furnace roasting of Tl-bearing pyrite (Steffes-Tun and Bambauer, 1990) and as an important secondary host phase of $\mathrm{Tl}$ in soils formed on carbonate rock hosting $\mathrm{Tl}(\mathrm{I})$-bearing metal sulfides (Voegelin et al., 2015; Herrmann et al., 2018).

Samples RT3, RT4, and RT5 display mainly quartz (above 60\%) and in general lower amounts of jarosite and hematite (Table 2). Traces of barite can also be found in all these samples. The most abundant phase in the clay fraction $(<2 \mu \mathrm{m})$ of these samples is plumbojarosite, followed by quartz, hematite and traces of muscovite and magnetite (Table 3). This mineralogy is in agreement with the quantification of their major 
elements (Table 4), i.e., mostly $\mathrm{Fe}$ in sample RT2 and a large amount of $\mathrm{Si}$ in the soil samples. Thallium total concentration in these samples decreases with distance from the iron-rich "telera" sample (RT2), down to $14 \mathrm{mg} \mathrm{kg}^{-1}$ in the far soil sample (RT5) (Fig. $1)$.

\subsection{Physico-chemical properties}

The $\mathrm{pH}$, electrical conductivity, surface area, pore volume and half pore width of the selected samples are compiled in Table 5. All samples display acidic pH values [2.1 3.2], being the sample RT2, rich in jarosite and with highest $\mathrm{Tl}$ content, the one with lowest $\mathrm{pH}$ value, highest electrical conductivity and highest surface area, and hence the most potential reactive sample. The acidity of this type of samples is common in polymetallic sulfide deposits that generate AMD. The leachates of acid solutions favor the dissolution and corrosion processes of resistant mineral phases such as quartz, which physico-chemical weathering processes can give rise to colloidal silica nanoparticles as were observed by TEM in most of the samples (see section 3.6). Sample of pyrite ore (RT16) has low $\mathrm{pH}$ values whereas sample RT4 shows the highest $\mathrm{pH}$ value (3.2) and the largest amount of jarosite. The dissolution of jarosite at low and high $\mathrm{pH}$ (2 and 8) is incongruent, with selective dissolution of $\mathrm{K}$ and $\mathrm{SO}_{4}$ compared to $\mathrm{Fe}$ (Smith et al., 2006). The most acidic dissolution yields only aqueous products whereas experiments carried out at higher $\mathrm{pH}$ values result in formation of nanoparticles of secondary goethite on the jarosite grain surfaces, which do not resorb either $\mathrm{K}$ or $\mathrm{SO}_{4}$. These surface coatings are probably responsible for inhibiting subsequent jarosite dissolution. Electrical conductivity (EC) also reflects the salinity of the samples that according to XRD results might be caused by the presence of sulfates. The highest values of surface area correspond to samples RT2 and RT4. The reactive surface area available increase exponentially when particle sizes decrease down to a nano-metric scale, below $100 \mathrm{~nm}$. In the case of these samples, they display significant amounts of colloid concentration and the highest total $\mathrm{Tl}$ content. Therefore these could potentially be the most toxic mine wastes.

\subsection{Microscopy observations and point chemical composition}

The ESEM pictures of particles $(<2 \mathrm{~mm})$ taken from RT16 and RT2 samples (Figs. 2a and $2 b$ ) show the mineral transformations of the ore samples resulting from the calcination process of pyrites in the pyrite roasting residues (“telera”). Iron oxides 
(mainly hematite) is the main product of the oxidation of pyrite, that usually forms at lower temperatures $\left(900-1000^{\circ} \mathrm{C}\right)$ and higher oxygen concentrations than those needed for magnetite $\left(\mathrm{Fe}^{3+}{ }_{2} \mathrm{Fe}^{2+} \mathrm{O}_{4}\right)$ formation ( $\mathrm{Hu}$ et al., 2006). The observed morphologies resemble pyrite grains (brittle pyrite in RT16) with signs of the roasting process (Figs. $2 \mathrm{c}$ and $2 \mathrm{~d}$, respectively). In the polished sections, a fluidal and an onion-shape outer layer product of the roasting process (not present in the brittle pyrite sample), can be observed in Figs. 2e and 2f, respectively. Direct pyrite oxidation proceeds with a shrinking unreacted core likely controlled by chemical reaction or the inward diffusion of oxygen due to the pore-blocking effect by the formation of ferric/ferrous sulfate $(\mathrm{Hu}$ et al., 2006). Besides, there are other granular and porous iron sulfide particles in RT16 (Fig. 2g) and iron oxides in RT2 that displays the effect of the roasting process (Fig. 2h). Even though pyrite is the main mineral phase in RT16 sample, this also contains minor amounts of micron-sized galena (PbS) crystals (Fig. 2i), whereas jarosite-like crystals can be observed in sample RT2, as a product of roasting and weathering processes (Fig. 2j).

ESEM results for soils samples collected around the roasted pyrite heap are compiled in Figure 3. Jarosite-like particles were observed in all samples. Iron oxides and oxyhydroxides were found in RT3 sample (Figs. 3a and 3b). Micron-sized particles (Fig. 3a) and flower-like morphologies (Fig. 3b) that resemble iron oxy-hydroxide with $S$, likely schwermannite $\left(\mathrm{Fe}^{3+}{ }_{16} \mathrm{O}_{16}\left(\mathrm{OH}_{12}\right)\left(\mathrm{SO}_{4}\right)_{2}\right)$, were also identified, although this phase was not detected by XRD due to its nano-crystalline structure and low proportion in the sample. Epitaxial growth shapes of an amorphous gel (with $\mathrm{Si}, \mathrm{Na}, \mathrm{Al}$ and $\mathrm{K}$, rich in $\mathrm{Tl}$ ) onto iron oxides crystals (with $\mathrm{Tl}$ ) and thin layers of iron oxides (with $\mathrm{Al}, \mathrm{Si}$ and $\mathrm{K}$, rich in $\mathrm{Tl}$ ) were detected in sample RT4 (Figs. 3c and 3d). Tl was not detected by EDS in most of the Fe oxides analyzed in the samples. Silica nanoparticles, mixtures of silicon and $\mathrm{Fe}$ oxides and $\mathrm{Pb}$-jarosites are observed in RT4 sample (Figs. 3e). Lastly, mixtures of silicon and iron oxides (with $\mathrm{As}, \mathrm{Pb}, \mathrm{Al}, \mathrm{S}$ ) were commonly found in RT5 sample (Fig. 3e)

The backscattered images did not show differences in density contrast that would have allowed localizing discrete Tl-bearing particles (with higher density). In addition, limited resolution and detection limit, as well as the overlapping of $\mathrm{S}$ and $\mathrm{Tl}$ peaks in the semi-quantitative EDS spectra prevented the localization and quantification of $\mathrm{Tl}$ by ESEM-EDS in the studied samples. 
EPMA microanalyses of $\mathrm{Tl}$ and companion elements were obtained from all selected samples and mineral specimens. Mean $\mathrm{Tl}$ point concentration as a function of mineral specimen and samples is shown in Table 6. The Tl-rich arsenical pyrite (sample RT16) contains a mean $\mathrm{Tl}$ point concentration equal to $0.12 \pm 0.03 \%$. The even distribution of $\mathrm{Tl}$ concentration in addition to the fact that no independent Tl-bearing mineral was found within the analyzed grains, indicate that $\mathrm{Tl}$ might be predominately present as isomorphic substitution of $\mathrm{Fe}$ in the lattice of pyrite grains as suggested by Fan et al. (2014) instead of being present as tiny $(0.1-1 \mu \mathrm{m})$ independent Tl-bearing minerals. Deditius and Reich (2016) compiled Hg, Tl, and Cd concentrations in arsenian pyrites from different environments. The solubility limit of $\mathrm{Tl}$ or $\mathrm{Hg}$ in arsenian pyrite was approximated by a ratio of metal/As $=1$. Ratios above this threshold would indicate the formation of multi-metallic $\mathrm{Tl}-\mathrm{Hg}$ mineral nanoparticles. The distribution of metal concentrations below the solubility limit suggests that hydrothermal fluids from which pyrite precipitate are dominantly under saturated with respect to $\mathrm{Hg}$ and $\mathrm{Tl}$ species, favoring the incorporation of these metals into the pyrite structure as solid solution. In contrast, the formation of metallic mineral nanoparticles in the pyrite matrix occurs when $\mathrm{Hg}$ and $\mathrm{Tl}$ locally oversaturate with respect to their solid phases at constant temperature (Reich et al., 2005; Deditius and Reich, 2016).

Other elements analyzed were found in low concentrations except for $\mathrm{Pb}$ (mean point concentration $0.20 \pm 0.19 \%$ ). In the rest of samples analyzed, $\mathrm{Tl}$ was mainly associated to Fe oxide particles showing a mean $\mathrm{Tl}$ point concentration ca. $0.1 \%$ in samples RT2 to RT4 decreasing down to $0.06 \pm 0.04 \%$ in RT5. In addition, point S mean concentrations from $0.14 \pm 0.17 \%$ in RT2 to $0.50 \pm 1.2 \%$ in RT4 were also found associated to Fe oxide particles. López-Arce et al. (2017) studied the mineralogical decomposition of Tlbearing pyrite during roasting, giving rise to its oxidation and phase transition into iron oxides at temperatures around $900^{\circ} \mathrm{C}$. Within this transformation, the formation of ferric/ferrous sulfate micron-size crystals after roasting at $400^{\circ} \mathrm{C}$ is a common step before the final crystallization of Fe oxides (hematite) nanoparticles at greater temperatures. Based on this, roasting temperatures achieved in the Riotinto Teleras could have reached up to $600^{\circ} \mathrm{C}$. These iron sulfate crystalline phases may contain high proportions of toxic elements such as Tl. Later natural weathering and further hydroxylation-hydration reaction processes under atmospheric conditions of both iron sulfates and iron oxides may produce their partial transformation into jarosite-like minerals. As a result of either partial roasting of pyrite or later natural mineral 
evolution, $\mathrm{Tl}$ is always found accompanied by sizable amounts of $\mathrm{S}$. Interestingly, while in RT2 sample, jarosite-like particles contained $0.06 \pm 0.02 \% \mathrm{Tl}$, in samples RT3, RT4, and RT5 Pb-jarosite minerals, containing an overall mean $\mathrm{Pb}$ point concentration equal to $8.4 \%$, showed $\mathrm{Tl}$ concentrations below the detection limit. The so-called 'A' sites in jarosite structure are commonly occupied by alkali ions such as $\mathrm{K}^{+}$or $\mathrm{Na}^{+}$(Forray et al., 2010) and thus, presumably, by $\mathrm{Tl}(\mathrm{I})$ (Zunic et al., 1994), but also by divalent cations such as $\mathrm{Pb}^{2+}$. Numerous substitutions have been reported showing that jarosite-like minerals are suitable for trapping potentially toxic metals in the environment (Forray et al., 2010; Aguilar-Carrillo et al., 2017). However, according to predicted Gibbs free energies of formation of a series of different metal-bound minerals of the alunite supergroup, it seems more favorable for the Pb-rich alunite minerals than for the Tl-rich ones (Gaboreau and Vieillard, 2004). Further research is needed to ascertain the metal selectivity of alunite minerals for this trapping role in polymetallic pollution events.

\subsection{X-ray absorption spectroscopy}

The analysis of the powdered bulk materials and embedded blocks of the size fraction $<2 \mathrm{~mm}$ of the samples RT2 and RT4 using XANES spectroscopy revealed no significant differences between the two bulk materials as well as between the bulk XANES and $\mu$-XANES spectra collected on three points of interest on polished blocks from both samples. The close match of the sample spectra with the spectrum of Tl(I)jarosite suggested that the vast majority of $\mathrm{Tl}$ in both samples was $\mathrm{Tl}(\mathrm{I})$ associated with jarosite (Fig. 4). This finding is in line with the previous observation of Tl-bearing jarosite in hematite-rich ash resulting from the roasting of Tl-rich pyrite in a fluid bed furnace (Steffes-Tun and Bambauer, 1990) and as an important secondary Tl-bearing mineral in soil formed on carbonate rock hosting a Fe-As-Tl-sulfide mineralization (Voegelin et al., 2015; Herrmann et al., 2018). With respect to the points analyzed on polished blocks, the XANES spectra indicating Tl(I)-jarosite were in discord with EPMA results suggesting that some of these points should correspond to $\mathrm{Tl}$ associated with Fe-oxides or Tl-free plumbojarosite. This apparent discrepancy may point to the occurrence of submicron-sized $\mathrm{Tl}(\mathrm{I})$-bearing jarosite particles, as previously observed in roasting ash (Steffes-Tun and Bambauer,1990), that cannot be resolved by EPMA probing a sample volume of about $5 \mu \mathrm{m}$ in diameter and a few $\mu \mathrm{m}$ deep. In addition, it should be noted that the sample volume probed by $\mu$-XANES spectroscopy is substantially larger than the volume probed by EPMA: Assuming samples to consist of 
$\mathrm{Fe}_{2} \mathrm{O}_{3}$, the absorption lengths of X-rays at the $\mathrm{Tl} \mathrm{L}_{\mathrm{III}}$-edge and of the $\mathrm{Tl} \mathrm{L}_{\alpha}$ line equal $\sim 60$ and $\sim 33 \mu \mathrm{m}$, respectively. Considering further that the beam was 50x50 $\mu \mathrm{m}^{2}$, the volume probed by the focused beam on the polished blocks was roughly 50x50x50 $\mu \mathrm{m}^{3}$.

\subsection{Sequential extraction procedure (SEP)}

The results of the sequential extraction procedure (Table 1) of trace elements from the raw pyrite, roasting wastes, and soil samples are listed in Table 7 . Very low percentages $(<2 \%)$ of $\mathrm{Tl}$ was bound to the exchangeable or hydroxide fraction (FI), being slightly higher in sample RT16. In samples RT16, RT2, and RT3, around 4\% of total Tl content was associated to FII, targeting Fe oxide-hydroxides type minerals. Thallium extracted in step III (targeting the oxidizable fraction, mainly sulphides) represents $1-2 \%$ of the total content in samples RT2 and RT3, whereas in samples RT4 and RT5 this fraction is negligible. Instead, in sample RT16, mainly composed by pyrite, the partitioning study indicates that only circa 9\% $\mathrm{Tl}$ is linked to sulfides. Lastly, most $\mathrm{Tl}$ (85-99\%) is concentrated in the residual fraction (RF) in all the studied samples. This means that $\mathrm{Tl}$ is mainly distributed in crystalized minerals, such as quartz or feldspar. The results from the SEP suggest that the extracting conditions established in the step III (targeting organic matter or sulfides) might not be efficient enough to dissolve massive pyrite materials. In fact, Li et al. (2007) developed a three-step SEP in which pyrite and reactive sulfides were efficiently removed from samples after pyrolysis at $550^{\circ} \mathrm{C}$ during $1 \mathrm{~h}$. According to Vanek et al. (2010), BCR SEP is efficient for predicting (i) adsorbed and easily soluble $\mathrm{Tl}$ species (e.g., bound to carbonates), and (ii) Tl species associated with primary silicates (feldspars, micas, etc.). On the contrary, a limited selectivity of the BCR SEP was found for oxide- and sulfide-associated Tl species. Specifically, the third SEP step, oxidation, was insufficient to dissolve sphalerite and a portion of $\mathrm{Tl}$ passed to the residual fraction. The disagreement with the results from XANES can be explained by the fact that jarosite and most well-crystallized iron sulfate are not dissolved in step II. Rather, these phases need stronger extracting conditions such as $0.2 \mathrm{M}$ NH4-oxalate at $\mathrm{pH} 3$ and $80^{\circ} \mathrm{C}$ (Drahota et al., 2014) or $4 \mathrm{M} \mathrm{HCl}$ after pyrolysis (Li et al., 2007) and thus $\mathrm{Tl}$ bound to iron sulfates is finally extracted in the residual fraction within the BCR SEP method.

The results compiled in Table 7 are in agreement with those from Martin et al. (2004) who studied $\mathrm{Tl}$ content and chemical speciation at 91 sites contaminated by water and tailings spilled from the settling pond of a pyrite mine into rivers in Aznalcóllar (Spain), 
where most of the $\mathrm{Tl}(\sim 75 \%)$ was in non-extractable forms (component of the particles or adsorbed to crystalline oxides). Moreover, Jakubowska et al. (2007) detected that, according to the $\mathrm{BCR}$ protocol, $\mathrm{Tl}$ in soils from a $\mathrm{Pb}-\mathrm{Zn}$ mine, was mainly found in the residual fraction but a significant fraction was related with Fe/Mn oxyhydroxides, possibly as Tl hydroxide.

\subsection{Determination of colloidal and soluble fraction.}

Thallium and companion metals $(\mathrm{Al}, \mathrm{Fe}, \mathrm{Pb}$, and $\mathrm{Cu})$ concentrations in the colloidcontaining suspensions, i.e. the dispersible colloid fractions (DCF, <1000 nm) and the dissolved fractions (DF, $<10 \mathrm{~nm}$ ) are shown in Table 8 . The pyrite ore sample RT16 showed the highest colloid concentration in the DCF $\left(\sim 3500 \mathrm{mg} \mathrm{kg}^{-1}\right)$ followed by the sample of iron oxides from the "telera" resulting from pyrite roasting (RT2, 3200 mg $\mathrm{kg}^{-1}$ ). The DCF of samples RT3 to RT5 contained a mean colloid concentration of $\sim 1750 \mathrm{mg} \mathrm{kg}^{-1}$. Despite the high DCF in all samples, $\mathrm{Tl}$ concentration in the colloidal fraction is low. Out of the total $\mathrm{Tl}$ content of the samples, less than $0.6 \%$ is released upon water extraction and, within this fraction, up to $50 \%$ in sample RT2 as well as $30 \%, 20 \%$, and $16 \%$ in samples RT3, RT16, and RT4, respectively, is contained in the colloid particles. In sample RT5, all Tl extracted within the DCF is included in the dissolve fraction (DF, <10 nm). This is in agreement with Cruz-Hernández et al. (2018) who detected a significant amount of water-soluble $\mathrm{Tl}(\mathrm{I})$ in samples from diverse mining areas. Casiot et al. (2011) demonstrated that most of the $\mathrm{Tl}$ from acid mine drainage (AMD) of a $\mathrm{Pb}-\mathrm{Zn}$ mine (Southern France) was found as $\mathrm{Tl}(\mathrm{I})$ in dissolution and the association of $\mathrm{Tl}(\mathrm{I})$ with colloidal particles, such as ferrihydrite $\left(\left(\mathrm{Fe}^{3+}\right)_{2} \mathrm{O}_{3} \cdot 0.5 \mathrm{H}_{2} \mathrm{O}\right)$, was minor. Our results show that in addition to the significant amount of $\mathrm{Tl}$ in the dissolved fraction, a sizable fraction of total $\mathrm{Tl}$ is associated to colloid-size particles, potentially dispersible into the soil-water system, and susceptible to be transported through atmospheric dust emissions. This colloid material is also rich in $\mathrm{Fe}, \mathrm{Pb}$, and $\mathrm{Cu}$ which may indicate the presence of alunite-like particles within the colloid fraction as the main Tl-hosting colloid particles becoming potential vectors for Tl pollution.

Figure 5 shows TEM images of particles from colloidal fraction (DCF, <1000 nm), where crystalline iron oxides and amorphous silica can be observed in RT2 sample (Figs. 5a and 5b). Iron-lead hydrous sulfates (jarosite and plumbo-jarosite) with diameters between 200 and $400 \mathrm{~nm}$ and amorphous silica nanoparticles were identified 
in RT4 sample (Fig. 5c). Even though these phases are more abundant in these samples, they have also been found in the rest of the samples. TEM-EDS analyses have not detected $\mathrm{Tl}$ in any of these samples because the superposition of $\mathrm{S}$ peak as above explained. The amorphous silica found in the studied samples could play a significant role in trapping hydroxyl-sulfates onto quartz particles and in a lesser extent surrounding or in some cavities of iron oxides particles, behaving as a cementing material as inferred from the EPMA microanalyses; mixtures of micron-size crystals of $\mathrm{Pb}-\mathrm{Fe}$ hydroxyl-sulfates and $\mathrm{Fe}$ oxy-hydroxides with variable amounts of silicon were detected mainly in samples RT4 and RT5.

The ion chromatography results obtained in the dissolved fraction are compiled in table S4 (sulfate anion concentration is included in Table 8). The concentration in solution of soluble salts indicates that sample RT2 has the highest total mass (3.6\% wt.) followed by sample RT3 (1.2\% wt.), and these are mainly composed by sulfates. Contrarily, the sample with the lowest amount of sulfates corresponds to sample RT4 with total mass of salt content non-existent. These latter results might be explained by the presence of well crystalized jarosite and anglesite minerals in this sample in agreement with those obtained in the mineralogical composition by XRD. Additional information is included in table S3.

\section{Conclusions}

Historical mining activities in the Riotinto mine district are responsible for elevated toxic heavy metal concentrations in the area, polluting soils and water reservoirs. The historic "telera" roasting system and the remaining conical heaps enriched in $\mathrm{Tl}$ and other metal(oid)s after the roasting process, have become a source of contaminants as they are exposed to environmental conditions. A combination of chemical, microscopic and spectroscopic analysis of the soil samples along a small creek collecting surface runoff from the "teleras" suggests that geogenic Tl might be originally hosted in the pyrite structure as solid solution. Calcination of the pyrite ores produced a transfer of $\mathrm{Tl}$ to $\mathrm{Tl}(\mathrm{I})$-substituted jarosite as an important secondary host phase for $\mathrm{Tl}$ in both the telera iron-rich roasting residues and soils samples.

Our experimental approach to study $\mathrm{Tl}$ solid phase speciation and mobility did not include the analysis of the element in surface runoff water and this information is important to fully understand $\mathrm{Tl}$ transportation in local environments. In addition, the applied protocol for separation of the colloid fraction is based on filtration techniques 
which define the fraction on the basis of an operationally defined size (1000-10 nm). In spite of these shortcomings, our results show that even though $\mathrm{Tl}$ is relatively stable and has low mobility mainly associated to the most stable and least extractable chemical pool of the samples, a small fraction is readily extracted within the dispersible colloidal fraction comprising both dissolved and colloidal $\mathrm{Tl}$.

Taking into account this dominant association to the residual fraction, the role of colloid-sized jarosite-like particles as $\mathrm{Tl}$ vectors could be considered one of the main transport mechanisms for $\mathrm{Tl}$ spreading in the studied system. This mobile fraction is probably responsible for the $\mathrm{Tl}$ pollution in the soils affected by seasonal surface runoff coming from historical mine residues and could also participate in other transport mechanisms such as aeolian deposition Further studies are required to assess mechanistic information on the $\mathrm{Tl}$ transfer from geologic materials to the soil-water system in order to anticipate to the adverse effect of this element to the environment and human health.

\section{Acknowledgements}

This work was funded under the Spanish National Plan for Scientific and Technical Research and Innovation through the project CTM2014-55321-P. The Synchrotron Radiation Source at the Karlsruhe Institute of Technology (Germany) is thanked for providing the beamtime at SUL-X beamline. We thank ICTAN (CSIC) for performing ion chromatography, Cenquior (CSIC) for sulfur analysis, and MNCN (CSIC) for ESEM-EDS analysis and support with XRD interpretation. The authors also thank technicians from ICA (CSIC) for XRD and Nitrogen isotherms analysis. Thanks as well to the Microscopy Center UCM for their support with EPMA and TEM analysis. 


\section{FIGURE CAPTIONS}

Figure 1. Google Earth images and Rio Tinto headwaters map of the studied area, showing the samples colected from the North and South areas of Riotinto mine district (SW Spain). a) Riotinto district in the Iberian Peninsula context; b) samples collected in Nerva area; c) samples collected in Zarandas area; d) Rio Tinto headwaters map from Olias and Nieto (2015).

Figure 2. Pictures of brittle pyrite ore from Riotinto mine district and open-air pyrite roasting residues ("telera") from XIX century (Fe oxides); a) sample RT16 (brittle pyrite ore) in Zarandas area; b) "Telera" sample RT2 (Fe oxides) in Nervas area; c) ESEM image of Fe sulfide (fissured pyrite cube) (RT16 sample); d) ESEM image of pyrite cube and currently Fe oxide after roasting in RT2 sample; e) polished section of pyrite particle in RT16 sample; f) polished section of Fe oxide with signs of roasting (former pyrite cube) in RT2 sample; g) polished section of granular Fe sulfide in RT16 sample; $h$ ) polished section of porous Fe oxide in RT2 sample; i) ESEM image of pyrite (Py) and galena (Gn) crystals in RT16 sample; j) ESEM image of jarosite and plumbojarosites (hydrated $\mathrm{Fe}-\mathrm{Pb}$ sulfates) in RT2 sample.

Figure 3. ESEM images (backscattered) of selected Riotinto samples. a) Botroidal masses of goethite and jarosite-like minerals in RT3 sample; b) hematite and Fe oxyhydroxide masses in RT3 sample; c) epitaxial growth onto Fe oxide and jarosite-like minerals in RT4 sample; d) detail of former image showing amorphous gel of $\mathrm{Si}, \mathrm{Fe}$, $\mathrm{Na}, \mathrm{Al}$ and $\mathrm{K}$ (rich in $\mathrm{Tl}$ ) onto iron oxides crystals; e) silica, mixtures of silicon and iron oxides rich in $\mathrm{Tl}$, and $\mathrm{Pb}$-jarosite crystals in $\mathrm{RT} 4$ sample; f) mixture of $\mathrm{Si}-\mathrm{Fe}$ oxides in RT5 sample.

Figure 4. Tl $\mathrm{L}_{\mathrm{III}}$-edge bulk XANES and $\mu$-XANES spectra collected on samples RT2 (black lines) and RT4 (gray lines) in comparison to the spectrum of Tl(I)-jarosite (red line). For both samples, one bulk spectrum and three $\mu$-XANES spectra are shown.

Figure 5. TEM images of colloidal fraction $(<1000 \mathrm{~nm})$ of selected Riotinto samples. a) crystalline iron oxides and amorphous silica in RT2 sample; b) detail of amorphous silica nanoparticles in RT4 sample; c) iron-lead hydrous sulfates (jarosite and plumbojarosite) and amorphous silica in RT4 sample. 


\section{References}

Aguilar-Carrillo, J., Villalobos, M., Pi-Puig, T., Escobar-Quiroz, I.N., Romero, F.M., 2017. Synergistic arsenic(V) and lead(II) retention on synthetic jarosite. I. Simultaneous structural incorporation behaviour and mechanism. Environmental Sciences: Processes Impacts. DOI: 10.1039/c7em00426e

Baceva, K., Stafilov, T., Matevski, V., 2014. Bioaccumulation of heavy metals by endemic Viola species from the soil in the vicinity of teh As-Sb-Tl mine "Allchar" Republic of Macedonia. International Journal of Phytoremediation, 16, 347-365.

Belzile, N., Chen, Y-W, 2017. Thallium in the environment: A critical review focused on natural waters, soils, sediments and airborne particles. Applied Geochemistry, 84, 218-243.

Bhargava, S.K., Garg, A., Subasinghe, N.D., 2009. In situ high-temperature phase transformation studies on pyrite. Fuel, 88, 988-993.

Bolea, E., Laborda, F., Castillo, J.R., 2010. Metal associations to microparticles, nanocolloids and macromolecules in compost leachates: Size characterization by asymmetrical flow field-flow fractionation coupled to ICP-MS. Analytica Chimica Acta, 661, 206-214.

Campanella, B,. Onor, M., D'Ulivo, A., Giannecchini, R., D'Orazio, M., Petrini, R., Bramanti, E., 2016. Human exposure to thallium through tap water: A study from Valdicastello Carducci and Pietrasanta (northern Tuscany, Italy). Science of the Total Environment, 548, 33-42.

Caritat P., Reimann, C., 2017. Publicly available datasets on thallium (Tl) in the environment-a comment on "Presence of thallium in the environment: sources of contaminations, distribution, and monitoring methods" by Bozena Karbowska, Environ Monit Assess (2016) 188:640 (DOI 10.1007/s10661-016-5647-y). Environmental Monitoring and Assessment, 189, 232.

Carrasco Martiañez I., 2000. Historia en la Faja Pirítica. Bocamina, 5, 8-49.

Casiot, C., Egal, M., Bruneel, O., Verma, N., Parmentier, M., Elbaz-Poulichet, F., 2011. Predominance of Aqueous Tl(I) Species in the River System Downstream from the Abandoned Carnoules Mine (Southern France). Environmental Science \& Technology, 45, 2056-2064.

Chen, Y.H., Wang, C.L., Liu, J., Wang, J., Qi, J.Y,, Wu, Y.J., 2013. Environmental exposure and flux of thallium by industrial activities utilizing thallium-bearing pyrite. Science China-Earth Sciences, 56, 1502-1509.

Cruz-Hernández, Y., Ruiz-García, M., Villalobos, M., Romero, F.M:, Meza-Figueroa, D., Garrido, F., Hernández-Alvarez, E., Pi-Puig, T., 2018. Fractionation and mobility of thallium in areas impacted by mining-metallurgical activities: identification of a water-soluble Tl(I) fraction. Environmental Pollution, 237, 154-165.

Deditius, A.P., Reich, M., 2016. Constraints on the solid solubility of $\mathrm{Hg}$, Tl, and $\mathrm{Cd}$ in arsenian pyrite. American Mineralogist ,101, 1451-1459.

Drahota, P., Grösslovà, Z., Kindlovà, H., 2014. Selectivity assessment of an arsenic sequential extraction procedure for evaluating mobility in mine wastes. Analytica Chimica Acta, 839, 34-43.

Fan, Y., Zhou, T.F., Yuan, F., Wu, M.A., 2014. Geological and geochemical constraints on the genesis of the Xiangquan TI-only deposit, eastern China. Ore Geology Reviews ,59, 97-108. 
Fergusson, J.E., 1990. The heavy elements: chemistry, environmental impact and health effects. Pergamon Press, Oxford, 614 p.

Ferrero Blanco, M.D., 1999. Capitalismo Minero y Resistencia Rural en el Suroeste Andaluz. Río Tinto, 1873-1900. $2^{\text {a }}$ edition, Huelva. Servicio de Publicaciones de la Universidad de Huelva, 240 p.

Forray, F.L., Smith, A.M.L., Drouet, C., Navrotsky. A., Wright, K., Hudson-Edwards,. K.A., Dubbin, W.E., 2010. Synthesis, characterization and thermochemistry of a $\mathrm{Pb}$-jarosite. Geochimica et Cosmochimica Acta, 74, 215-224.

Gaboreau, S., Vieillard, P.. 2004. Predictions of Gibbs free energies of formation of minerals of the alunite supergroup. Geochimica et Cosmochimica Acta, 68, 3307-3316.

García Palomero, F., 1992. Mineralizaciones de Riotino (Huelva): geología, génesis y modelos geológicos para su explotación y evaluación de reservas mineras. In: J.G.-G.J.M. Frías (Ed.), Recursos minerales de España. CSIC, Madrid, pp. 1325-1351.

Gomez-Gonzalez, M.A., Garcia-Guinea, J., Laborda, F., Garrido, F., 2015. Thallium occurrence and partitioning in soils and sediments affected by mining activities in Madrid province (Spain). Science of the Total Environment, 536, 268-278.

Gomez-Gonzalez, M.A., Voegelin, A., Garcia-Guinea, J., Bolea, E., Laborda, F., Garrido, F., 2016. Colloidal mobilization of arsenic from mining-affected soils by surface runoff. Chemosphere, 144, 1123-1131.

Herrmann, J., Voegelin, A., Palatinus, L., Mangold, S., Majzlan, J., 2018 .Secondary Fe-As-Tl mineralization in soils near Buus in the Swiss Jura Mountains. European Journal of Mineralogy. https://doi.org/10.1127/ejm/2018/00302766.Hu, G.L., Dam-Johansen, K., Stig, W., Hansen, J.P., 2006. Decomposition and oxidation of pyrite. Progress in Energy and Combustion Science, 32, 295314.

Jakubowska, M., Pasieczna, A., Zembrzuski, W., Swit, Z., Lukaszewski, Z., 2007. Thallium in fractions of soil formed on floodplain terraces. Chemosphere , 66, 611-618.

Karbowska, B., 2016. Presence of thallium in the environment: sources of contaminations, distribution and monitoring methods. Environmental Monitoring and Assessment, 188, 640, https://doi.org/10.1007/s 10661-0165647-y

Kersten, M., Xiao, T.F., Kreissig, K., Brett, A., Coles, B.J., Rehkamper, M., 2014. Tracing Anthropogenic Thallium in Soil Using Stable Isotope Compositions. Environmental Science \& Technology, 48, 9030-9036.

Li, J., Smart, R.S.C., Schumann, R.C., Gerson, A.R., Levay, G., 2007. A simplified method for estimation of jarosite and acid-forming sulfates in acid mine wastes. Science of the Total Environment ,373, 391-403

Lin, Z.X., Qvarfort, U., 1996. Predicting the mobility of $\mathrm{Zn}, \mathrm{Fe}, \mathrm{Cu}, \mathrm{Pb}, \mathrm{Cd}$ from roasted sulfide (pyrite) residues - A case study of wastes from the sulfuric acid industry in Sweden. Waste Management, 16, 671-681.

Lindsay, M.B.J., Moncur, M.C., Bain, J.G., Jambor, J.L., Ptacek, C.J., Blowes, D.W., 2015. Geochemical and mineralogical aspects of sulfide mine tailings. Applied Geochemistry ,57, 157-177.

Lis. J., Pasieczna, A., Karbowska, B., Zembrzuski, W., Lukaszewski, Z. Thallium in Soils and Stream Sediments of a $\mathrm{Zn}-\mathrm{Pb}$ Mining and Smelting Area. 2003. Environmental Science \& Technology, 37, 4569-4572. 
Lopez-Anton, M.A., Spears, D.A., Diaz-Somoano, M., Diaz, L., Martinez-Tarazona, M.R., 2015. Enrichment of thallium in fly ashes in a Spanish circulating fluidized-bed combustion plant. Fuel ,146, 51-55.

Lopez-Arce, P., Garcia-Guinea, J., Garrido, F., 2017. Chemistry and phase evolution during roasting of toxic thallium-bearing pyrite, Chemosphere, 181; 447-460.

Martin, F., Garcia, I., Dorronsoro, C., Simon, M., Aguilar, J., Ortiz, I., Fernandez, E., Fernandez, J., 2004. Thallium behavior in soils polluted by pyrite tailings (Aznalcollar, Spain). Soil \& Sediment Contamination,13, 25-36.

Olías, M., Nieto, J.M., 2015. Background Conditions and Mining Pollution throughout History in the Río Tinto (SW Spain). Environments ,2, 295-316.

Oliveira, M.L.S., Ward, C.R., Izquierdo, M., Sampaio, C.H., de Brum, I.A.S., Kautzmann, R.M., Sabedot, S., Querol, X., Silva, L.F., 2012. Chemical composition and minerals in pyrite ash of an abandoned sulphuric acid production plant. Science of the Total Environment, 430, 34-47.

Plathe, K.L., von der Kammer, F., Hassellov, M., Moore, J., Murayama, M., Hofmann, T., Hochella, M.F., 2010. Using FIFFF and aTEM to determine trace metalnanoparticle associations in riverbed sediment. Environmental Chemistry, 7, 8293.

Reich, M., Kesler, S.E., Utsunomiya, S., Palenik, C.S., Chryssoulis, S.L., Ewing, R.C., 2005. Solubility of gold in arsenian pyrite. Geochimica et Cosmochimica Acta ,69, 2781-2796.

Rodríguez-Mercado, J.J, Mosqueda-Tapia, G., Altamirano-Lozano, M.A., 2017. Genotoxicity assessment of human peripheral lymphocytes induced by thallium(I) and thallium(III). Toxicological \& Environmental Chemistry, 99, 987-998.

Romero, A., Gonzalez, I., Martin J.M., Vazquez, M.A., Ortiz, P., 2015. Risk assessment of particle dispersion and trace element contamination from mine-waste dumps. Environmental Geochemistry and Health,37, 273-286.

Sager, M., 1998 Thallium in agricultural practice, in J.O. Nriagu (Ed.), Thallium in the Environment, John Wiley \& Sons, New York, pp. 59-87.

Serrano, S., Gomez-Gonzalez, M.A., O`Day, P.A., Laborda, F., Bolea, E., Garrido, F., 2015. Arsenic speciation in the dispersible colloidal fraction of soils from a mine-impacted creek. Journal of Hazardous Materials, 286, 30-40.

Smith, A.M.L., Hudson-Edwards, K.A., Dubbin, W.E., Wright, K. 2006. Dissolution of jarosite $\left[\mathrm{KFe}_{3}\left(\mathrm{SO}_{4}\right)_{2}(\mathrm{OH})_{6}\right]$ at $\mathrm{pH} 2$ and 8: insights from batch experiments and computational modelling. Geochimica et Cosmochimica Acta, 70, 608-621.

Sobott, R.J.G., 1995. Minerals and calculated low-temperature phase equilibrium in the pseudoternary system $\mathrm{Tl}_{2} \mathrm{~S}-\mathrm{As}_{2} \mathrm{~S}_{3}-\mathrm{Sb}_{2} \mathrm{~S}_{3}$. Mineral Petrology, 53, 277-284.

Srinivasachar, S., Helble, J.J., Boni, A.A., 1990. Mineral behavior during coal combustion. 1. Pyrite transformations Progress in Energy and Combustion Science ,16, 281-292.

Steffes-Tun, W., Bambauer, H.U.. 1990. Immobilization of thallium in a pyrite ash dump by jarosite formation, in: Petruk, M., Hagni, R.D., Pignolet-Brandom, S., Hausen, D.M. (Eds.), Process Mineralogy IX. The Minerals, Metals \& Materials Society, pp. 411-414.

Tornos, F., Heinrich, C.A., 2008. Shale basins, sulfur-deficient ore brines and the formation of exhalative base metal deposits. Chemical Geology ,247, 195-207.

Tremel, A., Masson, P., Sterckeman, T., Baize, D., Mench, M., 1997. Thallium in French agrosystems - I. Thallium contents in arable soils. Environmental Pollution, 95, 293-302. 
Vanek, A., Chrastný, V., Komarek, M., Penizek, V., Teper, L., Cabala, J., Drábek, O., 2013. Geochemical position of thallium in soils from a smelter-impacted area. Journal of Geochemical Exploration, 124, 176-182.

Vanek, A., Grygar, T., Chrastny, V., Tejnecky, V., Drahota, P., Komarek, M., 2010. Assessment of the BCR sequential extraction procedure for thallium fractionation using synthetic mineral mixtures. Journal of Hazardous Materials ,176, 913-918.

Voegelin, A., Pfenninger, N., Petrikis, J., Majzlan, J., Ploetze, M., Senn, A-C., Mangold, S., Steininger, R., Göttlicher, J.,2015. Thallium Speciation and Extractability in a Thallium- and Arsenic-Rich Soil Developed from Mineralized Carbonate Rock. Environmental Science \& Technology, 49, 5390-5398.

Xiao, T.F., Guha, J., Boyle, D., Liu, C.Q., Zheng, B.S., Wilson, G.C., Rouleau, A., Chen, J., 2004. Naturally occurring thallium: a hidden geoenvironmental health hazard? Environment International ,30, 501-507.

Xiao, T.F., Yang, F., Li, S.H., Zheng, B.S., Ning, Z.P., 2012. Thallium pollution in China: A geo-environmental perspective. Science of the Total Environment ,421, 51-58.

Yan, R., Gauthier, D., Flamant, G., 2001. Partitioning of trace elements in the flue gas front coal combustion. Combustion and Flame ,125, 942-954.

Yang, C., Chen, Y., Peng P., Li, C., Chang, X., Wu, Y., 2009. Trace element transformations and partitioning during the roasting of pyrite ores in the sulfuric acid industry. Journal of Hazardous Materials ,167, 835-845.

Yang, C.X., Chen, Y.H., Peng, P., Li, C., Chang, X.Y., Xie, C.S., 2005. Distribution of natural and anthropogenic thallium in the soils in an industrial pyrite slag disposing area. Science of the Total Environment ,341, 159-172.

Zhou, D.X., Liu, D.N., 1985. Chronic Thallium poisoning in a rural area of Guizhou province, China. Journal of Environmental Health, 48, 14-18.

Zhuang, X.G., Su, S.C., Xiao, M.G., Li, J., Alstuey, A., Querol, X.,2012. Mineralogy and geochemistry of the Late Permian coals in the Huayingshan coal-bearing area, Sichuan Province, China. International Journal of Coal Geology, 94, 271282.

Zunic, T.B., Moelo, Y., Loncar, Z., Micheelsen. H., 1994. Dorallcharite, $\mathrm{Tl}_{0.8} \mathrm{~K}_{0.2} \mathrm{Fe}_{3}\left(\mathrm{SO}_{4}\right)_{2}(\mathrm{OH})_{6}$, a new member of the jarosite-alunite family. European Journal of Mineralogy. 6, 255-263. 


\section{TABLES}

Table 1. Sequential extraction steps for thallium fractionation ${ }^{\mathrm{a}}$

\begin{tabular}{|c|c|c|}
\hline Step & Extraction conditions & Hypothetical interpretation \\
\hline FI & $\begin{array}{l}20 \text { mL HOAc }(0.11 \mathrm{M}, \mathrm{pH} 2.8), 25^{\circ} \mathrm{C}, 16 \\
\text { h, continuous agitation }\end{array}$ & $\begin{array}{l}\text { exchangeable and associated with } \\
\text { carbonate }\end{array}$ \\
\hline FII & 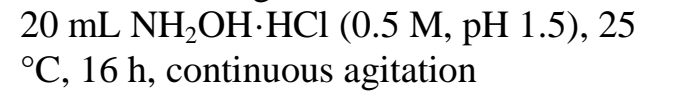 & $\begin{array}{l}\text { reducible; associated with Fe/Mn- } \\
\text { (hydr)oxides }\end{array}$ \\
\hline FIII & $\begin{array}{l}5 \mathrm{~mL} \mathrm{H}_{2} \mathrm{O}_{2}(30 \%), 85^{\circ} \mathrm{C}, 1 \mathrm{~h}, \text { intermittent } \\
\text { agitation; } 25 \mathrm{~mL} \mathrm{NH} \mathrm{NH}_{3} \mathrm{OAc}(1.0 \mathrm{M}, \mathrm{pH} \\
2.0), 25^{\circ} \mathrm{C}, 16 \mathrm{~h} \text {, continuous agitation }\end{array}$ & $\begin{array}{l}\text { oxidizable; associated with organic } \\
\text { matter or sulfides }\end{array}$ \\
\hline $\mathrm{RF}$ & $\begin{array}{l}\mathrm{HCl}: \mathrm{HNO}_{3}: \mathrm{HF} \text { (ratio 3.5:0.75:1.5), } \mathrm{H}_{3} \mathrm{BO}_{3} \\
(5 \%) \text {, } \\
\text { microwave-assisted digestion }\end{array}$ & $\begin{array}{l}\text { residual; associated with } \\
\text { aluminosilicates, other minerals }\end{array}$ \\
\hline
\end{tabular}

${ }^{\mathrm{a}}$ Procedure based on Yang et al.(2005). Initial sample weight $=0.5 \mathrm{~g}$.

Table 2. Semi-quantitative mineralogical composition of samples $<2 \mathrm{~mm}$ by powder Xray diffraction data (data in \%weight).

\begin{tabular}{lccccc}
\hline Mineralogy / samples & $\mathrm{RT} 16$ & $\mathrm{RT} 2$ & $\mathrm{RT} 3$ & $\mathrm{RT} 4$ & $\mathrm{RT5}$ \\
\hline Quartz $\left(\mathrm{SiO}_{2}\right)$ & 3 & 5 & 64 & 62 & 76 \\
Muscovite $\left(\mathrm{KAl}_{2}\left(\mathrm{Si}_{3} \mathrm{Al}\right) \mathrm{O}_{10}(\mathrm{OH}, \mathrm{F})_{2}\right)$ & $\mathrm{n} / \mathrm{d}$ & $\mathrm{n} / \mathrm{d}$ & $\operatorname{tr}$ & $\mathrm{n} / \mathrm{d}$ & 5 \\
Pyrite $\left(\mathrm{FeS}_{2}\right)$ & 71 & $\mathrm{n} / \mathrm{d}$ & $\mathrm{n} / \mathrm{d}$ & $\mathrm{n} / \mathrm{d}$ & $\mathrm{n} / \mathrm{d}$ \\
Chalcopyrite $\left(\mathrm{CuFeS}_{2}\right)$ & 26 & $\mathrm{n} / \mathrm{d}$ & $\mathrm{n} / \mathrm{d}$ & $\mathrm{n} / \mathrm{d}$ & $\mathrm{n} / \mathrm{d}$ \\
Jarosite $\left(\mathrm{KFe}^{3+}\left(\mathrm{OH}_{6}\left(\mathrm{SO}_{4}\right)_{2}\right)\right.$ & $\mathrm{n} / \mathrm{d}$ & 20 & 8 & 28 & 9 \\
Plumbojarosite $\left(\mathrm{PbFe}^{3+}{ }_{6}\left(\mathrm{SO}_{4}\right)_{4}(\mathrm{OH})_{12}\right.$ & & $\mathrm{n} / \mathrm{d}$ & $\operatorname{tr}$ & $\operatorname{tr}$ & $\operatorname{tr}$ \\
Hematite $\left(\mathrm{Fe}_{2} \mathrm{O}_{3}\right)$ & $\mathrm{n} / \mathrm{d}$ & 75 & 20 & 10 & 5 \\
Barite $\left(\mathrm{BaSO}_{4}\right)$ & $\mathrm{n} / \mathrm{d}$ & $\mathrm{n} / \mathrm{d}$ & $\operatorname{tr}$ & $\operatorname{tr}$ & 5 \\
Anglesite $\left(\mathrm{PbSO}_{4}\right)$ & $\mathrm{tr}$ & $\mathrm{n} / \mathrm{d}$ & 8 & $\mathrm{n} / \mathrm{d}$ & $\mathrm{n} / \mathrm{d}$ \\
\hline
\end{tabular}

tr: traces; $\mathrm{n} / \mathrm{d}$ : no detected

Table 3. Semi-quantitative mineralogical composition of clay $(<2 \mu \mathrm{m})$ fraction of selected samples by X-ray diffraction analysis (data in \% weight).

\begin{tabular}{lccc}
\hline Mineralogy / samples & RT3 & RT4 & RT5 \\
\hline Quartz $\left(\mathrm{SiO}_{2}\right)$ & 22 & 5 & 12 \\
Muscovite $\left(\mathrm{KAl}_{2}\left(\mathrm{Si}_{3} \mathrm{Al}\right) \mathrm{O}_{10}(\mathrm{OH}, \mathrm{F})_{2}\right)$ & 5 & tr & tr \\
Plumbojarosite $\left(\mathrm{PbFe}^{3+}{ }_{6}\left(\mathrm{SO}_{4}\right)_{4}(\mathrm{OH})_{12}\right.$ & 35 & 85 & 82 \\
Hematite $\left(\mathrm{Fe}_{2} \mathrm{O}_{3}\right)$ & 38 & 5 & $\mathrm{tr}$ \\
Magnetite $\left(\mathrm{Fe}^{2+} \mathrm{Fe}_{2}{ }_{2} \mathrm{O}_{4}\right)$ & $\mathrm{n} / \mathrm{d}$ & 5 & $\mathrm{tr}$
\end{tabular}

Tr: traces; n/d: no detected 
Table 4. Major and minor element concentration

\begin{tabular}{|c|c|c|c|c|c|c|c|c|c|c|c|c|c|}
\hline \multirow[b]{2}{*}{ Sample } & $\mathrm{Fe}$ & $S$ & $\overline{\mathrm{Al}}$ & $\mathrm{Si}$ & $\mathrm{K}$ & $\mathrm{Mn}$ & $\mathrm{Ba}$ & $\mathrm{Tl}$ & As & $\mathrm{Cu}$ & $\mathrm{Zn}$ & $\mathrm{Pb}$ & \multirow{2}{*}{$\begin{array}{c}\mathrm{Hg} \\
\mu \mathrm{g} \mathrm{kg}^{-1}\end{array}$} \\
\hline & \multicolumn{5}{|c|}{$\%$} & \multicolumn{7}{|c|}{$\mathrm{mg} \mathrm{kg}^{-1}$} & \\
\hline RT16 $^{\mathrm{a}}$ & 34 & 52 & 0.11 & 2 & 0.2 & 53 & 55 & 23 & 1075 & 596 & 501 & 1085 & 8890 \\
\hline RT2 & 46 & 2 & 0.07 & 1 & 0.1 & 34 & 215 & 122 & 821 & 476 & 186 & 3660 & 2220 \\
\hline RT3 & 18 & 2 & 1.10 & 24 & 0.6 & 41 & 615 & 27 & 1051 & 233 & 324 & 3684 & 9130 \\
\hline RT4 & 12 & 3 & 1.35 & 25 & 0.9 & 30 & 939 & 61 & 1206 & 304 & 292 & 6200 & $>10000$ \\
\hline RT5 & 9 & 1 & 1.50 & 34 & 0.7 & 24 & 2494 & 14 & 1936 & 279 & 93 & 6373 & 9335 \\
\hline
\end{tabular}

${ }^{\mathrm{a}}$ Average value of triplicate analysis

Table 5. Physico-chemical properties of the samples

\begin{tabular}{cccccc}
\hline Sample & $\mathrm{pH}$ & $\begin{array}{c}\text { Electrical } \\
\text { conductivity } \\
\left(\mu \mathrm{S} \mathrm{cm} \mathrm{cm}^{-1}\right)\end{array}$ & $\begin{array}{c}\text { Surface area } \\
\left(\mathrm{m}^{2} \mathrm{~g}^{-1}\right)\end{array}$ & $\begin{array}{c}\text { Pore volume } \\
\left(\mathrm{cm}^{3} \mathrm{~g}^{-1}\right)\end{array}$ & $\begin{array}{c}\text { Half pore } \\
\text { width } \\
(\text { Mode }) \AA\end{array}$ \\
\hline RT16 & 2.8 & 657 & 0.341 & 0.001 & 11.910 \\
RT2 & 2.1 & 2620 & 4.964 & 0.044 & 16.925 \\
RT3 & 2.3 & 1566 & 2.139 & 0.005 & 3.070 \\
RT4 & 3.2 & 293 & 4.854 & 0.010 & 3.925 \\
RT5 & 2.7 & 605 & 3.876 & 0.006 & 16.925 \\
\hline
\end{tabular}


Table 6. Element point mean concentration (wt.\%) in main mineral phases as determined by Electron Probe Microanalyses (EPMA)

\begin{tabular}{|c|c|c|c|c|c|c|c|c|c|c|c|c|c|c|c|c|c|}
\hline Sample & & $\mathrm{n}^{\mathrm{a}}$ & $\begin{array}{c}\mathrm{Tl}^{\mathrm{b}} \\
(0.048)\end{array}$ & $\begin{array}{c}S \\
(0.02) \\
\end{array}$ & $\begin{array}{c}\mathrm{Na} \\
(0.02) \\
\end{array}$ & $\begin{array}{c}\text { As } \\
(0.05) \\
\end{array}$ & $\begin{array}{c}\mathrm{Pb} \\
(0.02)\end{array}$ & $\begin{array}{c}\mathrm{Fe} \\
(0.015)\end{array}$ & $\begin{array}{c}\mathrm{Al} \\
(0.013)\end{array}$ & $\begin{array}{c}\mathrm{Si} \\
(0.038) \\
\end{array}$ & $\begin{array}{c}\mathrm{Ba} \\
(0.02)\end{array}$ & $\begin{array}{c}\mathrm{K} \\
(0.009) \\
\end{array}$ & $\begin{array}{c}\mathrm{Cu} \\
(0.02) \\
\end{array}$ & $\begin{array}{c}\mathrm{Sb} \\
(0.02) \\
\end{array}$ & $\begin{array}{c}\mathrm{Zn} \\
(0.02) \\
\end{array}$ & $\begin{array}{c}\mathrm{O} \\
(0.14) \\
\end{array}$ & Total $^{\mathrm{c}}$ \\
\hline RT16 & Pyrite & 32 & 0.12 & 52.8 & b.d. ${ }^{\mathrm{d}}$ & 0.06 & 0.20 & 44.8 & b.d. & 0.02 & b.d. & b.d. & 0.02 & 0.03 & 0.03 & b.d. & 99 \\
\hline \multirow[t]{2}{*}{ RT2 } & Iron oxide & 26 & 0.10 & 0.14 & b.d. & 0.06 & 0.07 & 62.7 & b.d. & b.d. & b.d. & 0.01 & b.d. & 0.07 & 0.02 & 27 & 91 \\
\hline & Jarosite & 3 & 0.06 & 6.3 & 0.48 & 0.13 & 1.55 & 34.2 & 0.06 & 0.06 & b.d. & 0.47 & 0.05 & 0.32 & b.d. & 21 & 65 \\
\hline \multirow[t]{3}{*}{ RT3 } & Iron oxide & 25 & 0.11 & 0.32 & b.d. & 0.12 & 0.67 & 55.9 & 0.08 & 0.76 & 0.04 & 0.06 & b.d. & 0.08 & 0.02 & 24 & 83 \\
\hline & $\mathrm{Pb}$-jarosite & 15 & b.d. & 7.6 & 0.23 & 0.80 & 13.4 & 27.8 & 0.10 & 1.28 & 1.65 & 0.97 & 0.09 & 0.23 & 0.03 & 27 & 81 \\
\hline & Barite & 11 & 0.14 & 14.1 & 0.18 & 0.19 & 1.11 & 2.4 & 0.49 & 0.46 & 54.5 & 0.10 & b.d. & 0.06 & b.d. & 29 & 103 \\
\hline \multirow[t]{2}{*}{ RT4 } & Iron oxide & 20 & 0.11 & 0.50 & 0.04 & 0.05 & 0.36 & 58.1 & 0.06 & 1.64 & 0.02 & 0.11 & b.d. & 0.10 & 0.02 & 27 & 88 \\
\hline & $\mathrm{Pb}$-jarosite & 24 & b.d. & 8.1 & 0.71 & 0.30 & 6.2 & 22.1 & 1.11 & 5.70 & 0.06 & 2.31 & 0.03 & 0.32 & b.d. & 31 & 78 \\
\hline \multirow[t]{3}{*}{ RT5 } & Iron oxide & 56 & 0.06 & 0.36 & b.d. & 0.54 & 0.20 & 59.6 & 0.39 & 0.68 & 0.04 & 0.06 & b.d. & 0.19 & 0.03 & 33 & 95 \\
\hline & $\begin{array}{l}\mathrm{Pb} \text {-jarosite } \\
\text { Iron oxide- }\end{array}$ & 7 & b.d. & 6.0 & 0.21 & 0.35 & 5.5 & 28.7 & 3.62 & 4.79 & b.d. & 1.72 & 0.08 & 0.39 & b.d. & 29 & 79 \\
\hline & Feldspar & 9 & 0.10 & 0.19 & b.d. & 0.25 & 0.16 & 35.2 & 8.1 & 12.34 & 0.37 & 3.12 & b.d. & 0.38 & b.d. & 38 & 99 \\
\hline
\end{tabular}

${ }^{a}$ Total number of point analyses on each mineral phase (at least three grains per sample)

${ }^{\mathrm{b}}$ Mean point element concentration from $\mathrm{n}$ analyses in wt.\%. Detection limits (wt.\%) are shown below each element.

${ }^{\mathrm{c}}$ Sum of mean concentrations $(\%)$

${ }^{\mathrm{d}}$ b.d. = bellow detection 
Table 7. Solid phase distribution of $\mathrm{Tl}$ from sequential extraction procedure ${ }^{\mathrm{a}}$

\begin{tabular}{|c|c|c|c|c|c|c|}
\hline & FI & FII & FIII & $\mathrm{RF}$ & $\begin{array}{l}\mathrm{Sum}^{\mathrm{d}} \\
\mathrm{mg} \cdot \mathrm{kg}^{-1}\end{array}$ & $\begin{array}{c}\text { Total }^{\mathrm{e}} \\
\mathrm{mg} \cdot \mathrm{kg}^{-1}\end{array}$ \\
\hline RT16 & 1.8 & 3.9 & 8.9 & 85 & 26.4 & 23 \\
\hline RT2 & 0.1 & 4.3 & 1.9 & 94 & 131.2 & 122 \\
\hline RT3 & 0.8 & 3.7 & 1.3 & 94 & 27.1 & 27 \\
\hline RT4 & 0.3 & 0.9 & 0.3 & 99 & 63.5 & 61 \\
\hline RT5 & 0.1 & 1.5 & 0.6 & 98 & 12.8 & 14 \\
\hline
\end{tabular}

${ }^{a}$ The sequential extraction procedure is described in Table 1

${ }^{b}$ Percentage of extracted $\mathrm{Tl}$ regarding the sum of the steps (FI+FII+FIII+RF)

${ }^{c}$ Extracted $\mathrm{Tl}$ as the sum of all steps (FI+FII+FIII+RF)

${ }^{\mathrm{d}}$ Total concentration of $\mathrm{Tl}$ in samples measured by ICP-MS

Table 8. Aluminum, $\mathrm{Fe}, \mathrm{Tl}, \mathrm{Pb}$, and $\mathrm{Cu}$ concentrations of the dispersible colloid fraction (DCF, <1000 nm), dissolved fractions (DF, <10 nm) and colloids (1000-10nm). Sulfate anion concentrations obtained by ion chromatography analysis of the dissolved fraction (DF, <10 nm).

\begin{tabular}{|c|c|c|c|c|c|c|c|c|c|c|c|c|c|}
\hline Sample & Fraction & $\mathrm{Fe}^{\mathrm{a}}$ & $\mathrm{Al}$ & $\mathrm{Tl}$ & $\mathrm{Pb}$ & $\mathrm{Cu}$ & $\mathrm{SO}_{4}=\mathrm{b}$ & $\begin{array}{l}\text { Colloid } \\
\text { conc. }^{c}\end{array}$ & $\mathrm{Fe}$ & $\mathrm{Al}^{\mathrm{d}}$ & $\mathrm{Tl}$ & $\mathrm{Pb}$ & $\mathrm{Cu}$ \\
\hline & & $\mathrm{mg} \mathrm{L}^{-1}$ & & $\mu \mathrm{g}$ & & & $\mathrm{mg} \mathrm{L}^{-1}$ & $\mathrm{mg} \mathrm{kg}^{-1}$ & & $\mathrm{mg} \mathrm{[}$ & $\mathrm{kg}$ collo & $d]^{-1}$ & \\
\hline \multirow[t]{3}{*}{ RT16 } & DCF & 114.0 & 870 & 13.03 & 4442 & 599 & & 3493 & 136.5 & 1.00 & 0.026 & 5.2 & 0.11 \\
\hline & DF & 100.0 & 770 & 10.39 & 3924 & 588 & 405 & & & & & & \\
\hline & Colloids & 13.6 & 100 & 2.64 & 517 & 11.0 & & & & & & & \\
\hline \multirow[t]{3}{*}{ RT2 } & DCF & 619.0 & 19530 & 2.31 & 7.8 & 5135 & & 3224 & 41.70 & 2.80 & 0.012 & 0.01 & 3.63 \\
\hline & DF & 615.0 & 19250 & 1.12 & 6.4 & 4772 & 3599 & & & & & & \\
\hline & Colloids & 4.2 & 280 & 1.19 & 1.4 & 363 & & & & & & & \\
\hline \multirow[t]{3}{*}{ RT3 } & DCF & 79.0 & 7020 & 14.79 & 3630 & 1628 & & 1492 & 7.48 & 1.30 & 0.044 & 4.1 & 1.51 \\
\hline & DF & 78.6 & 6890 & 10.35 & 3223 & 1477 & 1145 & & & & & & \\
\hline & Colloids & 0.75 & 130 & 4.44 & 407 & 151 & & & & & & & \\
\hline \multirow[t]{3}{*}{ RT4 } & DCF & 0.84 & $<\mathrm{QL}^{\mathrm{d}}$ & 2.31 & 13119 & 31.5 & & 1789 & 2.49 & & 0.004 & 16.8 & 0.09 \\
\hline & DF & 0.59 & $<Q L$ & 1.93 & 11430 & 22.4 & 24 & & & & & & \\
\hline & Colloids & 0.25 & & 0.38 & 1689 & 9.1 & & & & & & & \\
\hline \multirow[t]{3}{*}{ RT5 } & DCF & 2.74 & 6810 & 0.73 & 812 & 923 & & 1998 & 12.50 & 7.10 & 0.00 & 2.1 & 1.31 \\
\hline & $\mathrm{DF}$ & 1.49 & 6100 & 0.73 & 600 & 792 & 149 & & & & & & \\
\hline & Colloids & 1.25 & 710 & 0 & 212 & 130 & & & & & & & \\
\hline
\end{tabular}

${ }^{a}$ Element concentration expressed as $\mu \mathrm{g}$ of metal per liter of colloid suspension (DCF), dissolved fraction (DF), and colloids defined as the difference between the concentration of the metal in the DCF and the DF.

${ }^{\mathrm{b}}$ Sulfate anion concentrations obtained by ion chromatography analysis of the dissolved fraction (DF, <10 nm).

${ }^{\mathrm{c}}$ Colloid concentration as $\mathrm{mg}$ of colloids per $\mathrm{kg}$ of sample calculated according to Plathe et al. (2010)

${ }^{\mathrm{d}}$ Milligrams of metal per kilogram of colloids (1000-10 nm)

${ }^{\mathrm{e}}$ Below the quantification limit of the ICP-MS measurement. 
Historical roasting of thallium- and arsenic-bearing pyrite: Current $\mathrm{Tl}$ pollution in the Riotinto mine area

Paula López-Arce ${ }^{\mathrm{a}, 1}$, Fernando Garrido ${ }^{\mathrm{a}, *}$, Javier García-Guinea ${ }^{\mathrm{a}}$, Andreas Voegelin ${ }^{\mathrm{b}}$, Jörg Göttlicher ${ }^{\mathrm{c}}$, Jose Miguel Nieto ${ }^{\mathrm{d}}$

${ }^{a}$ Museo Nacional de Ciencias Naturales (CSIC), C/ José Gutierrez Abascal, 2, 28026, Madrid (Spain)

${ }^{\mathrm{b}}$ Eawag, Swiss Federal Institute of Aquatic Science and Technology, Department of Water Resources and Drinking Water, Überlandstrasse 133, CH-8600 Dübendorf (Switzerland)

${ }^{c}$ Karlsruhe Institute of Technology, Institute for Photon Science and Synchrotron Radiation, KIT Campus North, Hermann-von-Helmholtz-Platz 1, D-76344 EggensteinLeopoldshafen (Germany)

${ }^{\mathrm{d}}$ Department of Earth Sciences, University of Huelva, 21071 Huelva (Spain)

'Present address': The Bartlett School of Environment, Energy and Resources, University College London, 22 Gordon Street, London, WC1H 0QB, UK - Property Care Association, 11 Ramsay Court Kingfisher Way, Huntingdon, PE29 6FY, UK.

*Corresponding author.

Phone: +34914111328; E-mail: fernando.garrido@mncn.csic.es

\section{HIGHLIGHTS}

- Pyrite roasting residue from $19^{\text {th }} \mathrm{c}$. is a source of metal pollution in Riotinto mine

- We study Tl dispersion into soil by chemical, microscopic and spectroscopic methods

- $\quad \mathrm{Tl}(\mathrm{I})$-jarosite is the main mineral $\mathrm{Tl}$ hosting in soils

- $\mathrm{Tl}(\mathrm{I})$-jarosite may behave as colloid nanovector in $\mathrm{Tl}$ soil pollution 

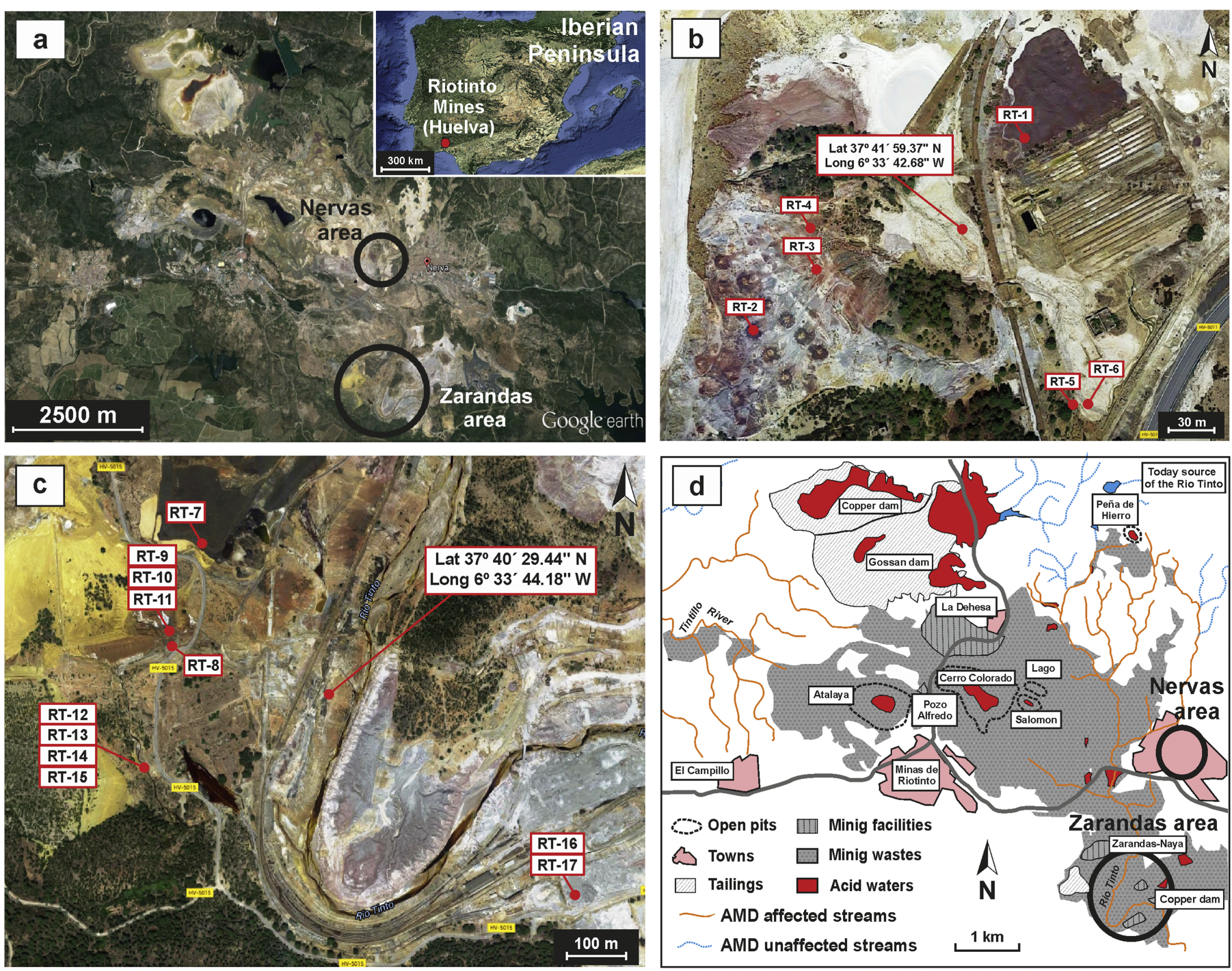

Figure 1 


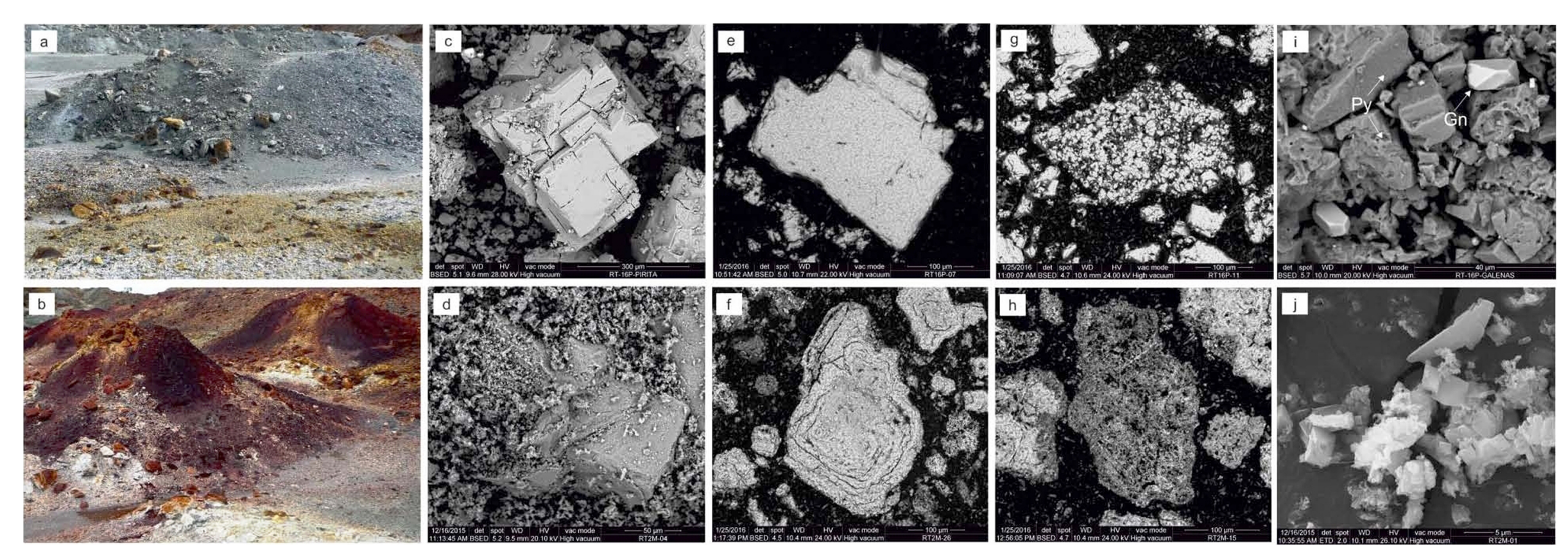



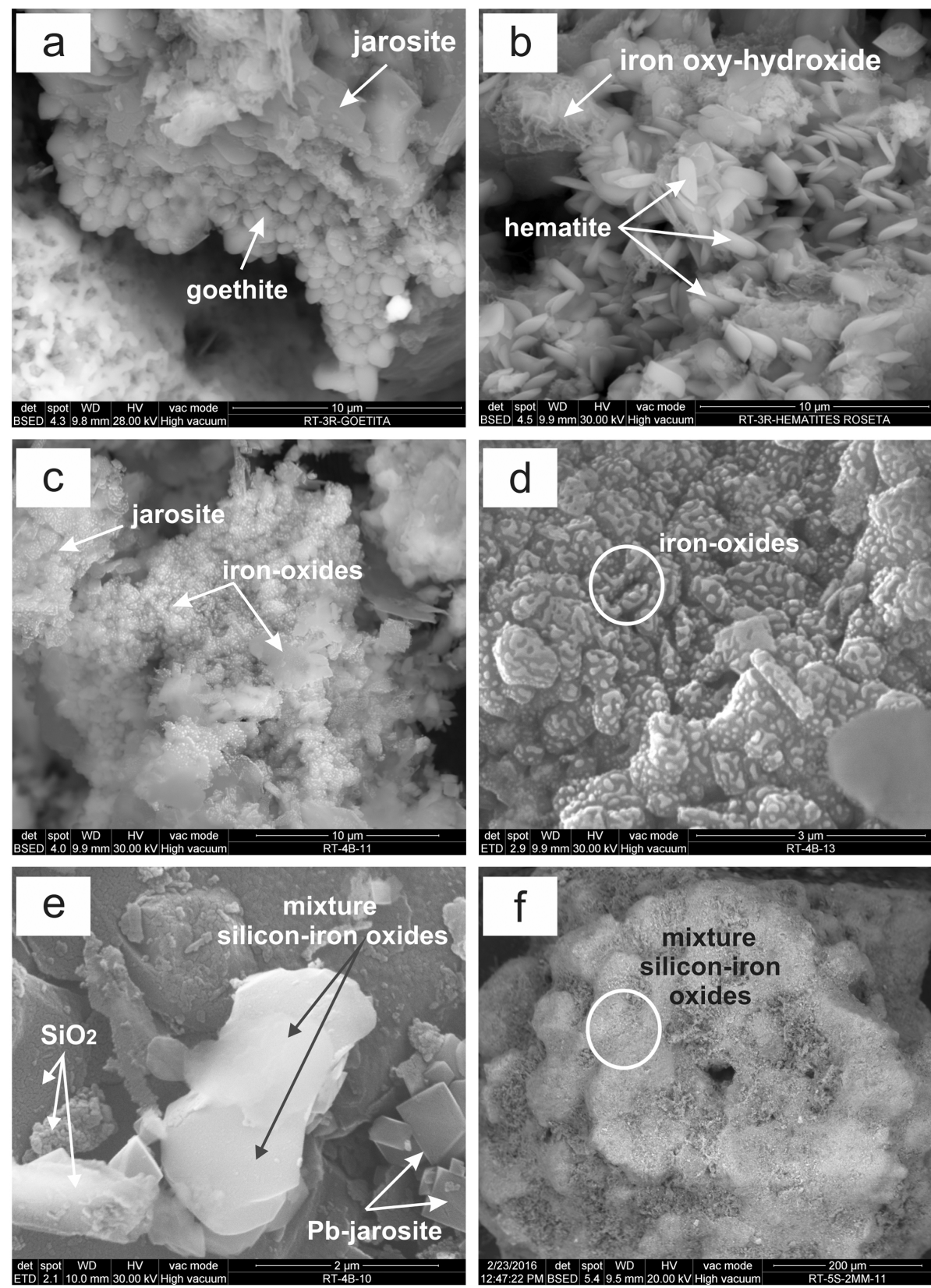

Figure 3 


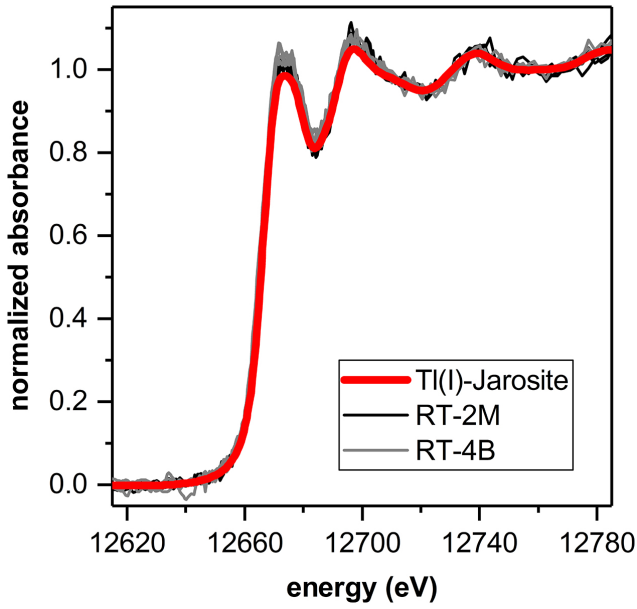

Figure 4 

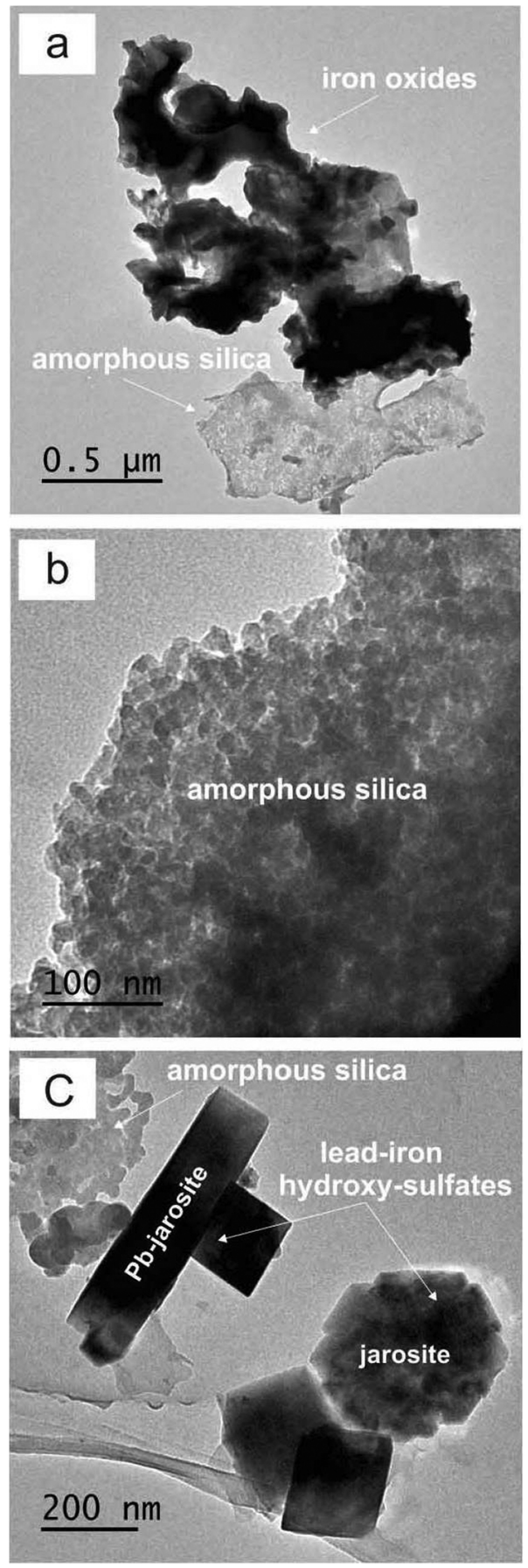

Figure 5 